\title{
PENGARUH MEDIA PELATIHAN DAN TINGKAT PENDIDIKAN TERHADAP KETERAMPILAN PEMBUATAN SANITASI RUMAH TINGGAL BERWAWASAN LINGKUNGAN Eksperimen pada Masyarakat Nelayan di Kabupaten Barru, Sulawesi Selatan, 2010
}

\author{
BAKHRANI RAUF \\ Dosen Universitas Negeri Makassar
}

\begin{abstract}
The objective of this research is to find out the effects of training media and the level of education on the skill to build the household sanitation based on environmental concern by the fisherman community in Barru Regency, South Sulawesi. The method used was a kind of experiment with $2 \times 2$ factorial design. The results of this research showed that; (1) the use of training media of model is better than the graphical media (drawing media), (2) there is an interaction found between the use of training media and education level of the fisherman in sanitation building, (3) the high level of education of fisherman in the skill of sanitation, gave a better result of the sanitation building, and (4) the modeling media gave better sanitation skill than the graphical media. It seems that the modeling media of training is better than the graphical media for the fisherman in the sanitation building.
\end{abstract}

Keywords: sanitation building, fisherman, modeling and graphical media

\section{PENDAHULUAN}

Undang-undang Republik Indonesia Nomor 32 tahun 2009 tentang Perlindungan dan Pengelolaan Lingkungan Hidup, menyebutkan bahwa setiap orang mempunyai hak atas lingkungan hidup yang baik, sehat, dan berkewajiban memelihara, melestarikan lingkungan hidup, mencegah, menanggulangi pencemaran dan perusakan lingkungan hidup. Atas dasar undang-undang tersebut, maka setiap warga negara bekewajiban menjaga mutu lingkungan, karena mutu lingkungan merupakan dasar dan pedoman untuk mencapai tujuan pengelolaan lingkungan.

Bila mutu lingkungan baik berarti kondisi lingkungan memadai dan berarti kualitas hidup manusiapun menjadi baik. Oleh karena itu, mutu lingkungan perlu ditata oleh manusia sebaik mungkin, dijaga dan dipelihara serta dicegah dari segala kemungkinan yang dapat merusak lingkungan. Salah satu unsur penting bagi tercapainya pembangunan berwawasan lingkungan adalah terwujudnya manusia sebagai pembina lingkungan hidup di manapun dia berada.

Survey oleh Joint Monitoring Program (JMP) tahun 2004, mengemukakan bahwa Indonesia masih menghadapi tantangan besar dalam mewujudkan akses sarana sanitasi, yaitu baru mencapai 55\% di bawah rata-rata, termasuk buang air besar di sembarang tempat. Hal ini menunjukkan bahwa $45 \%$ atau 100 juta masyarakat Indonesia masih berperilaku buang air besar (BAB) di sembarang tempat seperti: di pantai, sungai, sawah, kebun atau tempat terbuka lainnya.
Sanitasi lingkungan perlu mendapat perhatian khusus, karena menyangkut tinja dan air buangan serta sampah. Ketiga indikator ini merupakan sumber penyakit. Untuk membantu mempercepat kemajuan sanitasi lingkungan maka pada tahun 2008 di Manila Philipina ditetapkan sebagai tahun sanitasi Internasional (TSI) International year of Sanitation dengan slogan "Sanitation is the Solution". Keputusan Menteri Kesehatan No.825/Menkes/SK/IX/2008 tentang strategi nasional Sanitasi Total Berbasis Masyarakat (STBM) yang diadopsi dari program sanitasi International Community Led Total Sanitation (CTLS) adalah gerakan perubahan menuju pola Perilaku Hidup Bersih dan Sehat (PHBS) yaitu: (1) tidak membuang air besar (BAB) di sembarang tempat, (2) mengolah limbah cair rumah tangga yang aman, (3) mencuci tangan pakai sabun, (4) mengolah air minum dan makanan yang aman terhadap kesehatan, (5) mengolah sampah rumah tangga yang benar. Pemerintah pusat melalui Menteri Kesehatan pada tanggal 20 Agustus 2008 mencanangkan target pada tahun 2012 yaitu 10.000 desa sudah menerapkan Sanitasi Total Berbasis Masyarakat (STBM).

Menurut data badan kesehatan dunia World Health Organization (WHO) tahun 2007, sekitar 1,8 juta orang meninggal dunia setiap tahunnya atau sekiar 42.000 orang meninggal per minggu karena penyakit diare. Penyebab utamanya adalah sanitasi yang tidak memadai dan rendahnya standar kesehatan. Dari jumlah tersebut mayoritas kematian terjadi di Asia dan 90 \% korbannya adalah anak-anak berusia di bawah lima tahun atau sekitar 1,5 juta balita. Di 
Indonesia menurut survei demografi tahun 2006 yaitu sekitar $19 \%$ atau 100.000 anak balita meningal karena diare dan 423 per 1.000 anak balita terserang diare satu hingga 2 kali setahun. Sekitar 94\% kasus diare dapat dicegah dengan meningkatkan perbaikan sanitasi lingkungan. Data Departemen Kesehatan 2007 menunjukkan bahwa diare menjadi penyakit pembunuh kedua bayi di bawah lima tahun atau balita Indonesia setelah radang (pneumonia). Hal ini termasuk kasus kematian orang dewasa, anak-anak, dan balita yang ada di Kabupaten Barru, Propinsi Sulawesi Selatan.

Kabupaten Barru, Sulawesi Selatan mempunyai bentangan pantai sekitar $78 \mathrm{Km}$. Salah satu kecamatan yang mempunyai bentangan pantai yang panjang dan luas adalah Kecamatan Mallusetasi, yaitu sekitar 80 \% luas wilayahnya adalah pantai. Kecamatan ini memiliki 4 kelurahan dan 4 desa. Dua kelurahan dan dua desa berada pada daerah pantai yang dihuni oleh nelayan yang tingkat pendidikannya bervariasi yaitu tidak tamat SD, tamat SD, tidak tamat SMP, tamat SMP, tidak tamat SMA, dan tamat SMA.

Hasil survei yang dilakukan oleh peneliti Pebruari 2009 ditemukan masih rendahnya kualitas lingkungan yang dihuni oleh masyarakat nelayan, dilihat dari indikator: (1) membuang tinja di sembarang tempat; tidak ada usaha untuk membuat jamban keluarga yang aman terhadap kesehatan lingkungan; (2) tidak ada septictank yang permanen karena selalu tergenang air pasang; (3) membuang air cucian diatas rumah panggung sehingga kolong rumah becek akibat cucian; (4) tidak ada drainase (comberan) rumah panggung sehingga air cucian tidak mengalir; (5) air kebutuhan rumah tangga (air sumur) keruh dan tidak memiliki model penjernihan air bersih yang aman terhadap kesehatan manusia; (6) membuang sampah sembarangan karena tidak mempunyai tempat sampah yang permanen pada pekarangan rumahnya. Kesemuanya ini menandakan bahwa pengetahuan, sikap, dan keterampilan masyarakat nelayan dalam memelihara lingkungan, khususnya tentang pembuatan sanitasi rumah tinggal berwawasan lingkungan masih rendah.

Kurang lebih 99 \% rumah penduduk pada daerah pantai Kabupaten Barru, Sulawei Selatan adalah rumah panggung (Kabupaten Barru 2009). Kondisi fisik pemukiman pada umumnya datar yang diwarnai dengan mayoritas rumah panggung. Air pasang selalu naik dan menggenangi kolong rumah. Masyarakat di wilayah ini pada umumnya membuang tinja pada pinggir pantai dengan cara menggali pasir dengan kaki. Setelah selesai membuang tinja ditimbun kembali dengan pasir.

Ada beberapa jamban keluarga yang digunakan secara umum. Jamban umum tersebut selalu tergenang air pasang, bahannya terbuat dari kayu model panggung. Jamban tersebut tidak mempunyai dinding, atap, dan tidak menggunakan closet serta septictank (bak penampungan tinja). Akibatnya tinja jatuh pada air laut sehingga mencemari lingkungan.

Begitupun air buangan rumah tangga langsung dibuang pada tempat yang tidak konstruktif (langsung air cucian jatuh ke tanah pada kolong rumah). Beberapa tempat cucian masyarakat nelayan yaitu pada bagian bawah dibuatkan penadah air limbah cucian dengan menggunakan seng gelombang sehingga air limbah cucian dapat mengalir ke saluran air hujan pada bagian samping rumah panggung. Kondisi saluran pembuangan air cucian rumah tangga dan saluran air hujan hampir seluruhnya adalah saluran tanah yang tidak teratur.

Konsumsi air minum masyarakat pada umumnya sumur galian. Air sumur galian tersebut baik pada musim kering maupun musim hujan kondisinya tidak memenuhi syarat-syarat fisik air bersih karena keruh dan berlumpur. Masyarakat mengkonsumsi air tersebut secara turun temurun. Karena di daerah tersebut hanya mengandalkan air tanah untuk kebutuhan konsumsi air rumah tangga yaitu: mandi, mencuci pakaian, mencuci piring, air minum, dan lainlain. Secara visualisasi karakteristik air sumur di daerah tersebut adalah berwarna coklat dan mengandung lumpur, terutama pada musim penghujan. Alat penjernihan yang digunakan oleh kelompok masyarakat yang mengkonsumsi langsung air sumur sangat sederhana, yaitu air yang keruh bercampur lumpur tadi hanya ditampung dan ditenangkan pada suatu tempat (ember dan tempayan) yang lamanya kira-kira 6-12 jam. Selanjutnya, air tersebut dipakai mandi, mencuci pakaian, mencuci piring, memasak, dan sekaligus dimasak untuk air minum. Sistem penjernihan air yang dilakukan kelompok masyarakat nelayan tersebut di atas, kurang memenuhi syarat-syarat teknis, dan air yang dihasilkan tidak memenuhi syarat-syarat air minum.

Sampah buangan rumah tangga dibiarkan berserakan di daerah pantai dan tidak ada usaha masyarakat membersihkan sampah rumah tangga tersebut. Ada beberapa masyarakat hanya membuat lubang sampah di sekitar rumahnya, akan tetapi pada saat air pasang naik lubang tersebut penuh dengan air dan nyamuk bersarang, sehingga menimbulkan berbagai penyakit.

Hal ini kemungkinan disebabkan oleh kelompok masyarakat nelayan pada pemukiman pantai Kabupaten Barru: (1) belum sepenuhnya sadar lingkungan; (2) sikapnya terhadap kesehatan lingkungan masih cenderung negatif; (3) perilaku tentang sanitasi berwawasan lingkungan belum 
memadai; (4) tidak menemukan suatu konstruksi sanitasi rumah tinggal berwawasan lingkungan; (7) kurang mengetahui dan kurang terampil dalam pembuatan konstruksi sanitasi rumah tinggal berwawasan lingkungan yaitu: (a) konstruksi tiang rangka jamban keluarga model panggung, (b) konstruksi lantai, dinding, dan atap jamban keluarga model panggung, (c) konstruksi septictank dari buis beton dan instalasi pemipaannya, (d) konstruksi drainase (comberan) untuk rumah pangung, (e) konstruksi saringan penjernihan air bersih, (f) konstruksi tempat sampah rumah tangga.

Pengelolaan sanitasi rumah tinggal adalah keseluruhan rangkaian aktivitas seseorang dalam memberi respons terhadap objek tertentu yang terjelma melalui tindakan nyata dalam membuat: (1) sarana pembuangan kotoran manusia (jamban keluarga dan septictank); (2) sarana pembuangan air limbah; (3) sarana penjernihan air bersih; dan (4) sarana pembuangan sampah.

Untuk meningkatkan keterampilan masyarakat nelayan tentang perbaikan sanitasi rumah tinggal yang berwawasan lingkungan, perlu diberikan pelatihanpelatihan yang berkaitan dengan pembuatan sanitasi rumah tinggal yang berwawasan lingkungan di antaranya: (1) Keterampilan pembuatan dan pemasangan tiang rangka jamban keluarga model panggung; (2) Keterampilan pembuatan dan pemasangan tiang rangka jamban keluarga model panggung; (3) Keterampilan pemasangan septictank dari buis beton dan instalasi pemipaannya; (4) Keterampilan pembuatan dan pemasangan drainase (comberan) untuk rumah panging; (5) Keterampilan pembuatan dan pemasangan saringan penjernihan air bersih; (6) Keterampilan pembuatan dan pemasangan tempat sampah rumah tangga.

Dalam pelaksanaan pelatihan, terdapat beberapa pelatihan dengan menggunakan berbagai media (alat peraga) untuk membantu kelancaran pelatihan. Dari berbagai pelatihan dengan menggunakan media (alat peraga) dalam penelitian ini, dipilih pelatihan dengan menggunakan media tiga dimensi (media maket) dan menggunakan media grafis (media gambar) dalam rangka peningkatan keterampilan masyarakat nelayan tentang pembuatan sanitasi rumah tinggal yang berwawasan lingkungan.

\section{Perumusan Masalah}

Berdasarkan latar belakang, maka rumusan masalah penelitian ini adalah: (1) Apakah terdapat perbedaan keterampilan pembuatan sanitasi rumah tinggal berwawasan lingkungan antara kelompok masyarakat nelayan yang mengikuti pelatihan menggunakan media tiga dimensi (media maket) dengan yang menggunakan media grafis (media gambar)? (2) Apakah terdapat pengaruh interaksi antara media pelatihan dan tingkat pendidikan terhadap keterampilan masyarakat nelayan tentang pembuatan sanitasi rumah tinggal berwawasan lingkungan? (3) Apakah terdapat perbedaan keterampilan pembuatan sanitasi rumah tinggal berwawasan lingkungan antara masyarakat nelayan yang berpendidikan tinggi mengikuti pelatihan menggunakan media tiga dimensi (media maket) dengan yang menggunakan media grafis (media gambar)? (4) Apakah terdapat perbedaan keterampilan pembuatan sanitasi rumah tinggal berwawasan lingkungan antara masyarakat nelayan yang berpendidikan rendah mengikuti pelatihan menggunakan media tiga dimensi (media maket) dengan yang menggunakan media grafis (media gambar)?

\section{DESKRIPSI TEORETIK}

\section{Keterampilan Pembuatan Sanitasi Rumah Tinggal Berwawasan Lingkungan}

Keterampilan menurut pendapat atau teori yang disampaikan beberapa ahli antara lain: menurut Sage (1984: 17), istilah terampil diartikan sebagai suatu perbuatan atau pekerjaan dan sebagai indikator dari suatu tingkat keahlian. Suatu keterampilan dipandang sebagai aktivitas pekerjaan atau gerakan yang terdiri dari sejumlah tingkah laku dan persepsi yang diperoleh seseorang melalui belajar atau latihan untuk mencapai tujuan tertentu dengan sukses. Sedangkan Singer (1975: 34), terampil menunjuk pada derajat keberhasilan dalam bekerja dan mencapai tujuan dengan efektif dan efisien yang diwujudkan dalam bentuk perilaku kecepatan, kecermatan, ketepatan, dan kemampuan menyesuaikan diri dengan cepat karena keterampilan sebagai indikator dari suatu tingkat keahlian. Keterampilan diartikan sebagai kompetensi yang ditampilkan atau diperagakan oleh seseorang dalam melakukan suatu aktivitas atau pekerjaan yang berkaitan dengan pencapaian suatu tujuan. Jadi, semakin tinggi kemampuan seseorang dalam 
mencapai tujuan yang diharapkan, maka orang tersebut dipandang semakin terampil.

Berdasarkan pendapat tersebut dapat disimpulkan bahwa seseorang dapat dikatakan terampil apabila memilki kemampuan tinggi untuk melakukan pekerjaan atau aktivitas sehingga menghasilkan out put dengan kualitas tinggi yang diwujudkan dalam perilaku kecepatan, kecermatan, dan ketepatan dalam melakukan pekerjaan atau aktivitas.

Menurut Abramson dan Cohen mendiskripkan keterampilan adalah suatu kemampuan yang membawa pekerjaan atau tugas khusus dengan menggunakan kemampuan khusus pada jenis pelatihan dan pengalaman nyata. Dikatakan pula bahwa hampir semua studi mengenai keterampilan dilandasi pada pelatihan khusus. Sejalan dengan hal tersebut di atas Richald A. Magil (1988: 12) mengemukan bahwa keterampilan dapat diartikan sebagai rangkaian pekerjaan atau aktivitas dan tindakan. Keterampilan masyarakat suatu kualitas dari hasil/penampilan.

Menurut Schiever (1991: 8) keterampilan merupakan kemampuan khusus untuk melakukan tugas-tugas atau pekerjaan khusus. Hal ini diperjelas oleh Semiawan (1988: 17) bahwa kemampuan khusus itu antara lain adalah keterampilan menghitung, mencari hubungan ruang/waktu, meramalkan, dan mengkomunikasi-kan. Berdasarkan kedua pendapat tersebut, maka keterampilan yang dimaksudkan adalah kemampuan seseorang melakuan atau mengerjakan kegiatan tertentu dengan menggunakan pola-pola tingkah laku yang lengkap/kompleks dengan ditandai bahwa seorang lebih banyak menerapkan hitungan, mencari hubungan ruang dan waktu, meramalkan dan mengkomunikasi-kan hal-hal tertentu kepada orang lain.

Keterampilan dapat diperoleh seseorang melalui beberapa cara atau informasi, antara lain melaui sintem pembelajaran baik melalui pelatihan maupun pengalaman-pengalaman kerja. Hal ini berkaitan dengan apa yang dikemukakan oleh Davis, Bull, dan Roscoe (1995: 231) yang mengutip pendapat Knapp mendefinisikan keterampilan yaitu: suatu kemampuan seseorang yang diperoleh melalui suatu proses belajar atau latihan dengan usaha maksimal untuk meningkatkan hasil.

Keterampilan menurut Scmidt (1988: 17) adalah aktivitas seseorang yang kualitasnya bergantung pada latihan dan pengalaman individu dalam melakukan suatu aktivitas. Sedangkan Magil (1988: 12) mengemukakan keterampilan dapat diperlihatkan oleh seseorang dengan cara dan bentuk kemampuannya dalam menyelesaikan pekerjaan atau tugas yang berhubungan dengan materi-materi yang pernah dipelajarinya. Sejalan dengan pandangan
Behavioristik dalam Oemar Hamalik (1988: 175) mengemukan bahwa suatu keterampilan atau perilaku keterampilan pada dasarnya adalah stimulus respons yaitu keterampilan dapat diamati tentang bagaimana informasi masukan dan keluaran yang dihasilkan. Selanjutnya dijelaskan pula bahwa keterampilan merupakan kemampuan mencapai hasil atau keluaran yang maksimal dengan waktu dan usaha yang maksimal pula. Berkaitan dengan pendapat Warther, dan Davis (1993: 141) bahwa hal itu dapat saja diketahui dari indikasi-indikasi yang timbul pada diri seseorang yaitu faktor-faktor keterampilan seseorang dapat dilihat dari tingkat pengetahuan, pengalaman, serta kemampuan berkomunikasi. Ditambahkan pula bahwa tingkat pengetahuan dalam hal ini dibutuhkan, pengalaman paling tidak setahun pernah melakukan atau mempelajari atau melakukan pelatihan atau ikut dalam pekerjaan/tugas profesional lain. Kemampuan berbicara dan menulis adalah suatu kemampuan yang dimiliki seseorang untuk menyampaikan maksud secara efektif.

Indikator yang muncul pada diri seseorang sehingga ia dipandang terampil adalah apabila ia memiliki kemampuan dasar untuk mengerjakan atau melakukan suatu aktivitas tertentu yang dihadapinya dan dapat diselesaikan dengan baik berdasarkan pekerjan, seperti kemampuan dalam: (1) menghitung; (2) mencari hubungan ruang/waktu; (3) meramalkan; dan (4) mengkomunikasikan dengan orang lain dari berbagai hal yang dihadapinya.

Keterampilan menurut Bloom dalam Marzono dan Kendall (1981) bahwa ranah psikomotor berhubungan dengan hasil belajar yang pencapaianya melalui keterampilan yang melibatkan otot dan kekuatan fisik. Sedangkan Ryan (1980) menjelaskan bahwa hasil belajar keterampilan dapat diukur melalui: (1) pengamatan langsung dan penilaian tingkah laku peserta selama proses pembelajaran praktek berlangsung; (2) sesudah mengikuti pembelajaran yaitu dengan jalan memberikan tes kepada peserta untuk mengukur pengetahuan dan sikap. Selanjutnya Mondy dan Premeuk (1993: 16-18) mengemu-kakan bahwa keterampilan diukur dari tiga faktor antara lain: (1) keterampilan persiapan; (2) keterampilan proses; dan (3) keterampilan hasil.

Berdasarkan ketiga pendapat di atas, peneliti menyimpulkan bahwa keterampilan dapat dilihat dari aspek persiapan, proses, dan hasil berkaitan dengan keterampilan yang dikerjakan. Hal tersebut diperkuat oleh tulisan Zaifbio (2009: 2) tentang ranah penilaian kognitif, afektif, dan psikomotorik mengemukakan bahwa penilaian hasil belajar psikomotor atau keterampilan harus mencakup persiapan, proses, dan 
produk. Penilaian dapat dilakukan pada saat proses berlangsung, yaitu pada saat peserta melakukan praktek atau sesudah proses berlangsung dengan cara mengetes peserta.

Berdasarkan teori keterampilan seperti disebutkan di atas, seseorang dipandang atau dianggap memiliki keterampilan manakala orang itu mampu menerima informasi dan masukan kemudian dikelola dengan baik serta diwujudkan ke dalam bentuk tingkah laku yang berkualitas dalam menghasilkan out put yang berkalitas pula. Dengan demikian, ia lebih mudah mengkoodinasikan perilaku yang relatif untuk tujuan yang jelas sesuai yang diinginkan. Jadi, kesimpulan utama dari keterampilan seseorang adalah dapat diukur dari 3 aspek, yaitu: (1) terampil dalam melakukan persiapan dari seluruh rangkaian aktivitas atau pekerjaan yang hendak dilakukan; (2) terampil dalam seluruh rangkaian proses aktivitas atau pekerjaan yang dilakukan; dan (3) menunjukan kualitas hasil yang maksimal dari seluruh rangkaian pekerjaan yang dilakukan.

Masyarakat yang bermukim pada wilayah pantai perlu diberdayakan dengan cara dilatih tentang pembuatan sanitasi rumah tinggal berwawasan lingkungan. Keterampilan yang dimiliki oleh masyarakat ini akan menghasilkan lingkungan yang tertata dan memberikan kenyamanan dan kesejahteraan untuk dihuni jauh dimasa depan. Oleh karena itu, pelatihan membuat sanitasi rumah tinggal berwawasan lingkungan sangat mendukung keberlanjutan lingkungan sehingga masyarakat hidup sehat.

Menurut Azrul Aswar (1996: 22) pada hakikatnya masalah kesehatan lingkungan (sanitasi lingkungan) di Indonesia muncul sebagai akibat adanya dua faktor utama, yaitu: (1) faktor ketidak tahuan masyarakat; (2) terdapat faktor lingkungan yang kurang menguntungkan bagi kesehatan manusia. Sedangkan Slamet (1996: 10) kesehatan lingkungan 'environmental health' merupakan timbal balik antara manusia dan lingkungan yang berakibat mencegah kecelakaan, mencegah penyebaran penyakit bawaan air, udara, makanan, dan vektor. Konsep lingkungan ini dikaitkan dengan kegiatan-kegiatan manusia yang berhubungan dengan kesehatan misalnya: pembuangan tinja, pengolahan dan pembuangan air limbah, penyediaan air bersih, pembuangan sampah rumah tangga dan lain-lain.

Dari beberapa pengertian kesehatan lingkungan tersebut di atas dapat diketahui bahwa kesehatan lingkungan mencakup aspek yang sangat luas yang meliputi hampir seluruh aspek kehidupan manusia. Kesehatan lingkungan merupakan perluasan dari konsep-konsep hygiene dan sanitasi. Azrul Aswar (1996: 30) mengemukakan bahwa hygiene adalah usaha kesehatan masyarakat yang mempelajari pengaruh kondisi lingkungan terhadap kesehatan manusia. Upaya mencegah timbulnya penyakit karena pengaruh lingkungan kesehatan tersebut, serta membuat kondisi lingkungan sedemikian rupa sehingga terjamin pemeliharaan kesehatan. Sedangkan sanitasi adalah usaha kesehatan masyarakat yang menitikberatkan pada pengawasan terhadap berbagai faktor lingkungan yang mempengaruhi, atau mungkin mempengaruhi derajat kesehatan manusia.

Wisner dan Adams (2002:

127-128) mengemukakan bahwa sanitasi rumah tangga merupakan wahana hidup sehat, yang dipengaruhi oleh cara: (1) pembuangan kotoran manusia (tinja dan kencing manusia); (2) pembuangan air limbah rumah tangga (air buangan dapur, kamar mandi, tempat cucian); (3) saluran air bersih; (4) pengelolaan sampah. Apabila keempat faktor tersebut tidak terpenuhi dapat mengakibatkan buruknya sanitasi. Sedangkan menurut Ehles et al, (1988: 2) sanitasi merupakan upaya pencegahan berbagai penyakit dari lingkungan yang dapat ditularkan melalui aktivitas rutin manusia sehari-hari.

Sanitasi lingkungan pada semua kondisi yang mempengaruhi kesehatan atau upaya menghilangkan faktor-faktor lingkungan fisik yang terpengaruh terhadap kesehatan. Faktor-faktor fisik itu terutama yang disebabkan oleh keadaan lingkungan kurang bersih dan terinfeksi pada fasilitas rumah tinggal misalnya: pembuangan tinja manusia, saluran pembuangan air limbah, penyediaan air bersih, dan sarana pembuangan sampah.

Franceys Pickford \& Reed (1992: 3) yang tergabung dalam WHO memberi batasan terhadap sanitasi lingkungan sebagai suatu sistem penampungan dan pembuangan kotoran manusia 'septictank', limbah cair secara sehat, menjernihkan air yang keruh, dan membuang sampah yang berserakan, sehingga tidak membahayakan individu. Sanitasi merupakan pengembangan dan aplikasi, pengukuran sanitasi untuk keperluan kebersihan dan melindungi kesehatan. Sanitasi lingkungan yang buruk akan menimbulkan resiko kesehatan penduduknya, karena itu sanitasi lingkungan memfokuskan pada pembuangan tinja manusia, saluran pembuangan air limbah, penyediaan dan pengendalian air bersih, dan sarana pembuangan sampah.

Jadi, dengan demikian sanitasi lingkungan diartikan bahwa semua kondisi yang mempengaruhi kesehatan, atau suatu sistim penampungan atau penimbunan kotoran manusia, penanggulangan limbah cair secara sehat, penjernihan air bersih untuk kebutuhan manusia, serta sarana pembuangan sampah yang baik. Sanitasi lingkungan yang buruk akan menimbulkan resiko buruk pula terhadap kesehatan 
masyarakatnya. Oleh karena itu, sanitasi lingkungan memfokuskan pada sarana jamban keluarga dan septictank yang aman terhadap kesehatan manusia; sarana drainase dan saluran air limbah yang berwawasan lingkungan; sarana penjernihan air bersih yang aman terhadap kesehatan manusia; serta sarana pembuangan sampah rumah tangga yang aman terhadap kesehatan manusia dan lingkungan. Sanitasi lingkungan dapat dijelaskan sebagai berikut:

Kotoran manusia atau tinja merupakan sumber penyakit. Oleh karena itu, harus dibuang atau disimpan dalam jamban yang harus dimiliki setiap keluarga atau masyarakat di kawasan pemukiman tertentu seperti pemukiman pantai. Kotoran manusia merupakan buangan yang dikeluarkan oleh tubuh sebagai hasil proses akhir pencernaan manusia. Tinja yang tidak dikelola dengan benar dapat mempengaruhi kesehatan manusia karena: (1) bau busuk yang ditimbulkannya dapat merangsang datangnya lalat yang merupakan vektor penyakit; (2) tinja merupakan sumber beberapa penyakit terutama penyakit menular seperti tipus, kolera, disentri; (3) tinja dapat mencemari air tanah. Menurut Mc Donad dalam Chandra (2007: 125-126) bahwa di daerah tropis seperti Indonesia pengeluaran tinja berkisar antara 280 - 530 gr/orang/hari dan urine berkisar antara 600 1.130 gr/orang/hari.

Untuk mencegah dan mengurangi kontaminasi kotoran manusia terhadap lingkungan diperlukan pengelolaan pembuangan kotoran manusia secara benar misalnya membangun jamban keluarga dan septictank. Menurut Notoatmodjo (2007: 160) bangunan jamban keluarga harus memenuhi persyaratan kesehatan antara lain: (1) Jamban keluarga yang terlindungi terhadap panas dan hujan, serangga dan binatang lainnya serta sebaiknya tertutup; (2) ditempatkan pada lokasi yang tidak mengganggu pemandangan, dan tidak menimbulkan bau; (3) cukup air untuk membersihkannya. Sedangkan Salvato Josef dan Joe Beck (1994: 17) mengemukakan bahwa syarat jamban keluarga harus menggunakan ventilasi agar ada sirkulasi udara dan septic-tank harus menggunakan penutup dan lubang udara dari pipa sehingga bau dapat diminimalisasi. Dengan demikian, jamban keluarga harus memenuhi persyaratan kesehatan yaitu: terlindungi terhadap panas dan hujan, serangga dan binatang lainnya serta sebaiknya tertutup. Jamban keluarga ditempatkan pada lokasi yang tidak mengganggu pemandangan, dan dibuatkan ventilasi pada jamban serta penutup septictank sehingga serangga tidak masuk, dan tidak menimbulkan bau, serta cukup air untuk membersihkannya.

Rancangan jamban keluarga yang cocok untuk wilayah pemukiman pantai yang selalu tergenang air pasang yaitu: jamban keluarga dari kayu model paggung menggunakan closet dan instalasi pemipaan, mempunyai lantai, dinding dan ventilasi serta atap dan menggunakan septictank dari buis beton tertutup dan muncul pada permukaan air pasang. Tinja tidak terkontaminasi dengan air pasang laut, dan serangga tidak masuk, serta tidak menimbulkan bau, sehingga terhindar dari berbagai penyakit.

Kusnoputranto (1997: 1) mengemukakan bahwa air limbah rumah tangga adalah air limbah yang tidak mengandung ekskreta manusia dan dapat berasal dari buangan kamar mandi, dapur, tempat cuci piring, tempat cuci pakaian dan lain-lain, yang mungkin mengandung mikro organisme pathogen dalam jumlah kecil. Menurut Hakim Rustam (2008: 193) yang dimaksud limbah cair hasil kegiatan manusia adalah air buangan yang berasal dari pemakaian air mandi, air cucian, dan WC. Air limbah yang berasal dari daerah pemukiman (domestik) terutama yang terdiri atas tinja, air kemih, dan buangan air limbah lain (kamar mandi, dapur, serta cucian yang kira-kira mengandung 99,9 \% zat cair dan 0,1 \% zat padat)

Slamet (1996: 126) mengemukakan bahwa air limbah atau air buangan adalah semua air yang dibuang sebagai sisa kegiatan manusia yang tidak dipergunakan lagi yang termasuk dalam kategori air buangan adalah air bekas mandi, bekas cuci pakaian, bekas cuci piring, serta bekas cuci perabot dan bahan makanan. Aswar (1996: 22) mengemukakan bahwa untuk tidak terganggu kesehatan masyarakat, maka air buangan rumah tangga harus memenuhi beberapa persyaratan kesehatan lingkungan yaitu: (1) tidak sampai mengotori sumber air minum; (2) tidak menjadi tempat berkembang biaknya berbagai penyakit dan vektor; (3) tidak terganggu estetika; (4) tidak mencemari lingkungan sekitar.

Supaya persyaratan kesehatan lingkungan tersebut dapat tercapai dengan baik, diperlukan sistem pembuangan air limbah yang memenuhi persyaratan sanitasi lingkungan berupa: dainase (comberan) pembuangan air cucian pada rumah panggung, yang dilapisi saringan yaitu: lapian dasar batu pecah, ijuk, dan kerikil, kemudian air limbah yang sudah tersaring dialirkan menuju saluran air hujan. Menurut Babitt dan E. Bannana (1969: 346) suatu bangunan drainase saluran pembuangan air limbah dapat dikatakan memenuhi persyaratan sanitasi apabila terpenuhi syarat-syarat di antaranya: (1) air buangan dapat mengalir lancar sehingga tidak menjadikan air buangan sebagai sarang vektor penyakit; (2) tidak menimbulkan bau; (3) tidak bocor sehingga air buangan tidak mencemari lingkungan sekitar; (4) jika menggunakan pipa maka pemasangannya harus menggu-nakan pipa besar dan kemiringannya harus diperhitungkan dan terhindar dari bocor sehingga air 
limbah buangan tidak merembes ke mana-mana sehingga tidak terjadi becek.

Bentuk rumah tinggal masyarakat pada daerah pantai di Kabupaten Barru khususnya dan Sulawesi Selatan pada umumnya 99\% adalah rumah panggung. Kegiatan masyarakat di atas rumah panggung adalah: buang air kemih, buang air bekas mandi, buang air cuci piring, dan buang limbah cucian lain. Air limbah tersebut mengandung 99,9\% zat cair dan 0,1 \% zat padat, sehingga rancangan drainase saluran pembuangan air limbah rumah tangga yang cocok diterapkan yaitu: Drainase (comberan) pada kolong rumah panggung berbentuk segi empat. Comberan terbuat dari dinding pasangan batu merah ketinggian $20 \mathrm{~cm}$ dan dimasukkan lapisan dasar batu pecah, ijuk dan kerikil, yang ditempatkan lurus di bawah tempat cuci rumah panggung sehingga air limbah cucian dapat tertampung dan tersaring pada comberan kemudian mengalir menuju saluran pembuangan air hujan. Dengan adanya konstruksi drainase (comberan) rumah panggung ini, air limbah yang jatuh pada kolong rumah panggung dapat dialirkan sehingga terhindar dari berbagai penyakit.

Air merupakan kebutuhan pokok bagi manusia. Oleh karena itu, dalam rangka mempertahankan kelangsungan hidupnya, manusia berusaha mendapatkan air yang cukup bagi dirinya. Kenyataannya, banyak anggota masyarakat di pedesaan, menggunakan air yang tidak sesuai dengan persyaratan kesehatan. Sering ditemukan air yang dipergunakan mengandung bibit atau zat tertentu yag dapat menimbulkan penyakit dan dapat pula membahayakan kelangsungan hidup manusia. Selanjutnya Babbit (1969: 338-346) penyakit-penyakit infeksi yang biasanya ditularkan melalui air adalah tipus, kolera, disentri, cacingan, dan keracunan logam.

Di Negara-negara berkem-bang, terutama pada masyarakat pedesaan, sumber air minum yang biasanya dipakai adalah air tanah (sumur). Air tanah di dalam sumur pada umumnya tergolong bersih dilihat dari segi mikrobiologi karena proses pengaliran air mengalami penyaringan alamiah, tetapi yang menjadi masalah biasanya air dalam sumur tersebut tercemar oleh air kotor dari air limbah.

Wisner dan Adams (2002: 108) mengemukakan bahwa sumur sebagai sumber air bersih yang dipakai oleh masyarakat harus memenuhi persyaratan sanitasi lingkungan sebagai berikut: (1) sumur digali pada kedalaman minimal tiga meter karena bakteri tidak hidup pada kedalaman tersebut; (2) dibangun jauh dari sumber kontaminasi bakteri pathogen maupun unsur kimia yang merugikan; (3) bibir sumur sebaiknya ditembok untuk menghindari perembesan air permukaan yang biasanya sudah tercemar. Lanjut Wisner dan Adams (2002: 117-118) mengemukakan bahwa membersih-kan air sumur yang keruh dapat dilakukan dengan penyaringan yang dapat dibuat dari gentongan dengan menggunakan kran dengan memberikan lapisan penyaringan, yaitu: kerikil pada lapisan dasar, kemudian ijuk, kerikil, pasir, dan lapisan atas adalah kawat ram. Sumber air yang digunakan oleh masyarakat pantai di Kabupaten Barru pada umumnya menggunakan air sumur, tetapi airnya keruh sehingga tidak dapat langsung diminum, harus didiamkan dulu pada ember beberapa jam baru bisa digunakan. Oleh karena itu, konstruksi saringan penjernihan air keruh yang cocok digunakan adalah ember yang dasarnya diletakkan saringan penjernihan lapisan kerikil, pasir, dan ijuk sebagai saringan penjernih dan dialirkan dengan kran sebagai air kebutuan rumah tangga. Sehingga persyaratan air bersih dari segi persyaratan fisik (jernih, tidak berbau, dan $\mathrm{pH}$ sekitar 7) dapat terwujud.

Menurut Cointrean (1982: 4), sampah adalah suatu barang atau material yang dibuang atau dilepas sebagai yang tidak bernilai. Sampah adalah bahanbahan sisa yang tidak dipergunakan lagi termasuk sampah padat dan cair yang dibuang ke lingkungan permukaan. Di daerah pedesaan, sampah juga merupakan masalah yang sukar dipecahkan. Sampah yang tidak ditangani secara benar dapat mencemari air melalui selokan atau sarana air buangan. Sampah yang berakumulasi dan tidak dikelola dengan baik akan menjadi sarang vector penyebab penyakit misalnya: lalat dan tikus.

Sampah yang dihasilkan dari rumah tangga berdasarkan sifatnya dapat dibedakan menjadi sampah organik (degradable refuce) adalah sampah yang mengandung senyawa-senyawa organik sehingga dapat diurai (didegradasi) oleh decomposer atau mikroba, misalnya: daun, sisa sayur-sayuran, buahbuahan, ranting kayu, sisa-sisa makanan dan kertas. Adapun sampah an organik (non degradable refuce) adalah sampah yang tersusun dari bahan an organik sehingga tidak dapat diurai (didegradasi) oleh decomposer atau mikroba, misalnya: plastik, gelas (kaca) logam (metal), dan keramik.

Menurut Poldum (1980: 5) ada beberapa cara yang dapat dilakukan untuk pengelolaan atau pembuangan sampah, antara lain: (1) sistem terbuka, yaitu pembuangan sampah dilakukan dengan meletakkan sampah di suatu tempat tertentu dan dibiarkan terbuka dan dibiarkan sampah membusuk dengan sendirinya; (2) sistem pembakaran, yaitu pembuangan sampah dengan cara membakar sampah dari sistem terbuka; (3) sistem timbun atau ditanam, yaitu sistim pembuangan sampah dengan cara menimbun sampah; (4) sistem kompostin yaitu membuat sampah menjadi pupuk. 
Masyarakat nelayan pada wilayah pantai di Kabupaten Barru pada umumnya membuang sampah rumah tangga langsung pada pinggiran pantai sehingga dapat mencemari lingkungan. Rancangan tempat sampah yang cocok digunakan pada masyarakat pantai adalah tempat sampah dari papan atau pasangan batu merah yang menggunakan penutup dari papan sehingga tidak menimbulkan bau, dan setelah tinggal beberapa hari sampah daun-daun dan sisa makanan dijadikan kompos. Sampah plastik dijadikan kerajinan yang dapat bernilai ekonomi. Sampah yang tidak ditangani secara benar dapat mencemari air melalui air pasang, selokan atau sarana air buangan limbah.

Rumah tinggal menurut Rapoport (1997: 4-5.) berguna untuk melindungi manusia, aktivitas dan segala miliknya dari "musuh" (alam, manusia, hewan, dan kekuatan adikodrati), menyediakan tempat, menciptakan suatu kawasan yang aman, menunjukkan identitas sosial dan status. Izarwisama (1985: 24) rumah tinggal adalah tempat berindung dari panas matahari dan binatang buas. Hal ini menyimpulkan bahwa rumah tinggal merupakan tempat berteduh, membangun hidup secara fisik dan spiritual dan tempat membangun keluarga sejahtera. Menurut Kron, Joan (1983: 23-24) rumah tinggal tidak saja perlu indah, tetapi juga nyaman ditempati.

Menurut Johannes Linn (1983: 120) fungsi rumah memiliki: (1) struktur atau bangunan; (2) infrastruktur, prasarana bagi gerak manusia, perhubungan dan komunikasi, sirkulasi tenaga materi untuk kebutuhan jasmani, serta pelayanan (service) yang mencakup pendidikan, kesehatan, rekreasi, dan budaya. Sedangkan Koentjaraningrat (1994: 67) ditinjau dari bentuk rumah terdiri dari: (1) rumah setengah di bawah tanah (semi subteranian dwelling), (2) di atas tanah (surface dwelling), (3) di atas tiang (pile dwelling). Menurut Frick Heinz (2006:1) rumah harus menjamin kepentingan keluarga, yaitu untuk tumbuh, memberi kemungkinan untuk hidup bergaul dengan tetangganya lebih dari itu, rumah harus memberi ketenangan, kebahagiaan, dan kenyamanan pada segala peristiwa hidupnya .

Bentuk rumah tinggal nelayan yang ada di Sulawesi Selatan adalah rumah di atas tiang (pile $d$ welling) atau rumah panggung yang berfungsi sebagai tempat berteduh, tempat membina keluarga, serta tempat beraktivitas keluarga yaitu: tidur, makan, minum, buang air, mencuci dan lain-lain. Dari semua aktivitas keluarga tersebut membutuhkan sanitasi rumah tinggal yang baik dan berwawasan lingkungan seperti: jamban keluarga, drainase pembuangan air limbah rumah tangga, penyaringan air bersih, serta tempat pembuangan sampah sehingga melahirkan keluarga yang sehat dan sejahtera.
Menurut Parker, Sybil P (1980: 265) secara ekologis, lingkungan merupakan kumpulan semua kondisi-kondisi eksternal yang mempengaruhi kehidupan serta perkembangan organisme. Ada dua aspek utama yang dijumpai pada suatu lingkungan yaitu; (1) abiotik (tidak hidup), dan (2) biotik (hidup). Odum (1997: 8) mengemukakan bahwa organisme hidup lingkungan tidak hidup selalu berhubungan erat dan tidak dapat dipisahkan serta mempengaruhi satu sama lain.

Dari pengertian ini lingkungan merupakan semua kondisi eksternal baik abiotik maupun biotik yang mempengaruhi kehidupan dan perkembangan organisme. Sumaatmaja (1989: 27-29) mengemukakan bahwa lingkungan dapat diartikan sesuatu yang berada di sekitar manusia, yang dapat dibedakan dalam beberapa kategori: (1) lingkungan fisik (biotik) yang termasuk di dalamnya adalah tanah, air dan udara serta interaksinya; (2) lingkungan biotik yaitu semua organisme yang hidup seperti: binatang, tumbuhtumbuhan, mikroorganisme, kecuali manusia itu sendiri; (3) lingkungan sosial yaitu semua interaksi antarmanusia yang dapat menimbulkan kaidah-kaidah hubungan sosial, ekonomi, kebudayaan, dan psikososial. Menurut Soemarwoto (1995: 73) pengelolaan lingkungan hidup merupakan usaha sadar manusia dalam memelihara dan memperbaiki mutu lingkungan agar kebutuhan dasar dapat terpenuhi sebaik-baiknya. Wuryady (1997: 17) Secara lebih operasional menjelaskan, pengelolaan lingkungan mengandung makna memanfaatkan, menata, mengatur, membatasi, meningkatkan, dan melindungi lingkungan bagi kesinambungan daya dukungnya terhadap kebutuhan hidup manusia.

Soemarwoto (1995: 73) mengemukakan bahwa pengelolaan lingkungan dapat diartikan sebagai usaha sadar memelihara atau dan memperbaiki mutu lingkungan agar kebutuhan dasar kita dapat terpenuhi sebaik-baiknya. Menjaga mutu lingkungan adalah hal yang sangat penting karena lingkungan merupakan dasar dan pedoman mencapai tujuan pengelolaan lingkungan. Bila mutu lingkungan baik berarti kondisi lingkungan baik dan berarti pula kualitas hidup manusia pun menjadi baik. Oleh karena itu, mutu lingkungan perlu ditata sebaik mungkin, dijaga, dan dipelihara serta dicegah dari segala kemungkinan yang dapat merusak lingkungan. Unsur penting bagi tercapainya pembangunan berwawasan lingkungan adalah terwujudnya manusia sebagai pembina lingkungan hidup di manapun berada.

Adapun tujuan pengelolaan lingkungan hidup menurut Husein (1995: 51), adalah mewujudkan pembangunan berkelanjutan berdasarkan pelestarian lingkungan yang serasi, selaras, dan seimbang dalam rangka menuju peningkatan kesejahteraan 
manusia. Amsyari (1996: 107), mengemukakan bahwa lingkungan hidup bagi manusia mempunyai dua peran besar yakni lingkungan sebagai tempat tinggal dan lingkungan sebagai tempat mencari makanan serta kebutuhan lainnya. Apabila keadaan lingkungan sebagai tempat tinggal (pemukiman) tidak baik kualitasnya dan tidak mampu memberikan kecukupan kebutuhan hidup manusia maka akan mengakibatkan gangguan kesehatan. Lingkungan hidup menurut Salim (1993: 32) adalah segala benda, kondisi, keadaan, dan pengaruh dalam ruang yang ditempati dan mempengaruhi hal yang hidup termasuk kehidupan manusia. Sedangkan Sumarwoto (1995: 73) menjelaskan bahwa lingkungan hidup adalah ruang yang ditempati suatu mahluk hidup bersama dengan benda hidup dan tali hidup yang ada di dalamnya.

Berdasarkan uraian tentang lingkungan hidup dapat dipahami bahwa lingkungan terdiri atas dua bagian penting yakni: lingkungan fisik dan lingkungan sosial. Lingkungan fisik seperti pada pemukiman daerah pantai, perlu diperbaiki dan ditata sehingga tidak memberikan dampak negatif terhadap lingkungan secara keseluruhan.

Menurut Soerjani, dkk. (1987: 253) wawasan adalah pandangan, tinjauan penglihatan dan tanggap inderawi. Seseorang memiliki tanggap inderawi artinya orang tersebut mempunyai rasa kepedulian terhadap peristiwa-peristiwa yang terjadi di sekitarnya yang tampak melalui panca inderanya yang akhirnya akan melahirkan rasa tanggung jawab untuk turut mengatasinya. Sanidhal dan Robertson yang dikutip oleh Baron dan Byrne (1991:541) menggunakan istilah "Masyarakat yang bertanggung jawab terhadap lingkungan" sebagai padanan istilah "masyarakat yang berwawasan lingkungan”, masyarakat yang bertanggung jawab terhadap lingkungan adalah: (1) masyarakat yang memperhatikan masalah-masalah lingkungan lokal seperti: polusi air, polusi tanah, polusi udara, dan pengelolaan kotoran dan lain-lain; (2) masyarakat yang mendukung peraturan lingkungan seperti: pengaturan pembuangan sampah dan lain-lain; (3) masyarakat yang berperilaku ekologis seperti: membuang tinja pada jamban, mengalirkan air limbah rumah tangga ke saluran pembuangan. Dengan demikian, masyarakat yang berwawasan lingkungan adalah masyarakat yang bertanggung jawab dan memperhatikan masalah lingkungan lokal seperti: pencemaran lingkungan, mendukung peraturan lingkungan seperti: pengelolaan sampah rumah tangga, serta berperilaku ekologis seperti: jamban keluarga, limbah rumah tangga yang tidak mencemari lingkungan, dan pengadaan air bersih yang aman terhadap kesehatan manusia.

Koberg dan Bagnal dalam Lang Jon (1987: 4748) mengemukakan bahwa arsitektur adalah ilmu yang mempelajari desain bangunan, sedangkan perancangan adalah sebuah proses berpikir dari deduktif ke induktif. Sedangkan Sullivan Louis dalam Antoniades (1980: 176) menyebutkan bahwa dalam merancang suatu bangunan sebaiknya memperhatikan "form follow function" artinya bentuk mengikuti fungsi. Von Foerster dalam Laurens (2005:1) mengemukakan bahwa "Apa yang kita bentuk dalam pikiran, itulah realitas yang bisa kita wujudkan” namun realitas itu tidak selalu seperti yang diinginkan. Sedangkan Vitruvius dalam Zahnd (2009: 25) mengemukakan bahwa ada tiga hal yang perlu diperhatikan dalam merancang bangunan, yaitu: (1) fungsi; (2) struktur; dan (3) keindahan. Dikaitkan dengan rancangan sanitasi rumah tinggal berwawasan lingkungan, sebelum diterapkan kepada masyarakat harus melalui proses perancangan yaitu: berdasar pada fungsi bangunan itu sendiri, struktur terkait dengan konstruksi bangunan, dan keindahan terkait dengan bentuk bangunannya. Sesuai dengan fungsi, struktur dan keindahan yang dibentuk dalam pikiran perancang, itulah realitas yang dapat diwujudkan.

Perilaku berwawasan lingkungan adalah perilaku atau perbuatan manusia yang secara sadar terhadap lingkungan dengan dilandasi konsep tanggung jawab. Perilaku berwawasan lingkungan merupakan lawan dari mentalitas frontier. Menurut Chiras (1990: 456458) kerusakan lingkungan disebabkan oleh ulah manusia yang bermental frontier yaitu: (1) sumber kekayaan alam tidak terbatas; (2) manusia bukan bagian dari alam; (3) alam ada untuk dikuasai dan digunakan dalam pemenuhan kebutuhan manusia. Salim (1993) menyatakan bahwa pembangunan berwawasan lingkungan yaitu pembangunan yang memberi pemahaman tentang bagaimana mengelola sumber daya alam secara bijaksana sehingga terwujud pembangunan berkesinambungan bagi peningkatan kualitas hidup rakyat, generasi demi generasi sepanjang masa.

Dari uraian-uraian di atas dapat disimpulkan bahwa pelatihan keterampilan pembuatan sanitasi rumah tinggal berwawasan lingkungan adalah: kemampuan suatu masyarakat untuk hidup sehat dapat diwujudkan melalui pelatihan pembuatan dan pemasangan: (1) tiang rangka jamban keluarga model panggung; (2) lantai, dinding dan atap jamban keluarga model panggung; (3) bak penampungan tinja (septictank) dari bius beton dan instalasi pemipaannya; (4) drainase (comberan) untuk rumah panggung; (5) saringan penjernihan air bersih; dan (6) tempat sampah rumah tangga. 


\section{Media Pelatihan}

Uno (2007: 65-66) mengemukakan bahwa media pembelajaran orang dewasa adalah alat yang digunakan untuk menyampaikan pesan atau informasi dari pengajar atau instruktur kepada peserta. Media yang berisi pesan akan memberikan informasi dari sumber ke penerima, gunanya untuk memberi masukan serta menambah informasi atau keterampilan. Agar belajar berhasil seoptimal mungkin, maka peran media sangat penting. Menurut Clark dan Solomon dalam Plomp dan Ely (1996) mengemukakan bahwa pengaruh media sebagai (1) teknologi; (2) tutor atau guru; (3) alat bersosialisasi; (4) motivator dalam pembelajaran; (5) alat untuk menggugah mental tinggi dan memecahkan masalah. Sedangkan Bruner dalam Schaefer, Gitlin, dan Sandgrund (1991: 229-237) mengemukakan bahwa agar belajar lebih efektif dan mencapai hasil maksimal, penggunaan media konkret terlebih dahulu sebelum ke bentuk simbolik akan mempermudah menghubungkan dengan pengalaman sampai pemahaman abstrak.

Notoatmodjo (2007: 62) mengemukakan bahwa alat bantu atau media pendidikan adalah alat-alat yang digunakan oleh pendidik dalam menyampaikan bahan pendidikan atau pengajaran, dan diterima melalui indra. Kurang lebih $75 \%$ sampai $87 \%$ dari pengetahuan manusia diperoleh dan disalurkan melalui indra mata, sedangkan 13\% - 25\% lainnya tersalur melalui indra lain. Menurut Baugh dalam Arsyad Azhar (2009: 10) kurang lebih 90\% hasil belajar seseorang diperoleh dari indera pandang dan hanya 5\% diperoleh melalui indera dengar dan 5\% lagi melalui indera lainya. Sedangkan L.A Hill dalam Yaumi (2003: 51) mengatakan bahwa satu kali kekuatan mata sama dengan 22 kali kekuatan telinga.

Menurut Haney dan Ullmer dalam Miarso (2007: 462-465) mengemukakan bahwa ada tiga kategori utama berbagai bentuk media pembelajaran yaitu: (1) media penyaji adalah media yang mampu menyajikan informasi seperti: grafis, media proyeksi diam, media audio, audio ditambah media visual diam, gambar hidup (film), televisi, dan multimedia; (2) media objek adalah media yang mengandung informasi seperti: objek sederhana dan objek pengganti; (3) media interaktif adalah media yang memungkinkan untuk bereaksi. Media grafis dalam penelitian ini dibuat melalui proses gambar, sedangkan media tiga dimensi sebagai media objek pengganti yaitu: benda-benda yang dibuat oleh manusia untuk mewakili atau menggantikan "benda-benda yang sebenarnya" dikenal dengan nama: model (media maket), replika, dan benda tiruan. Model atau media maket merupakan sebuah reproduksi yang kelihatannya sama tetapi diperkecil atau dipebesar dalam skala tertentu seperti: gedung atau bangunan-bangunan lain.

Smaldino, Lowther dan Russell (2008: 84) mengemukakan bahwa dalam perancangan media untuk diterapkan pada masyarakat sebaiknya mengikuti ASSURE model: (1) Analyze learners yaitu menganalisis masyarakat; (2) State Standards objectives yaitu menyatakan tujuan; (3) Select strategies, technology, media and materials yaitu metode pembuatan, teknologi, dan bahan yang dibutuhkan; (4) Utilize tehnology, media, and materials yaitu pemanfaatan media dan bahanbahannya; (5) Require learner participation yaitu melibatkan partisipasi masyarakat; (6) Evaluate and revise yaitu mengevaluasi dan merevisi kalau ada usulan masyarakat. Selanjutnya Smaldino, Lowther dan Russel (2008: 58-60) membagi enam jenis media visual, yakni: (1) Realistic menunjukkan obyek sebenarnya atau konkret; (2) Analogical merupakan konsep untuk menunjukkan sesuatu yang lain atau mirip sesuatu yang dirujuk; (3) Organizational merupakan hubungan kualitatif antara elemen; (4) Relational merupakan hubungan kuantitatif; (5) transformational mengilustrasikan gerakan atau perubahan menurut waktu dan ruang; (6) Interpretive mengilustrasikan hubungan teoretis atau abstrak. Berdasarkan enam jenis media visual tersebut maka dapat disederhanakan menjadi dua bagian yakni media obyek yang sebenarnya konkret atau disebut media tiga dimensi (media maket) dan media objek abstrak atau disebut media grafis (media gambar).

Menurut Silberman (1990: 1) pelatihan adalah metode untuk meningkatkan penampilan kemampuan seseorang. Pelatihan aktif terjadi ketika banyak peserta melakukan berbagai kegiatan. Lynton dan Pareek (1978: 15) mengemukakan bahwa pelatihan adalah kegiatan yang dirancang untuk meningkatkan kinerja dalam pekerjaan yang diserahkan kepada mereka, berlangsung dalam jangka waktu pendek antara dua sampai tiga hari hingga dua sampai tiga bulan, dan dilakukan secara sistematis menurut prosedur yang terbukti berhasil dengan metode yang telah baku dan sesuai, dijalankan secara sungguh-sungguh dan teratur.

Menurut Kennet N Wexley, Gary Latham (1971: 156) program pelatihan menekankan kepada pembelajaran keterampilan (skill), pengetahuan, dan sikap yang dibutuhkan untuk melaksanakan pekerjaan dan tugas. Pelatihan dapat pula diartikan sebagai suatu proses pembelajaran dengan memberikan keterampilan tertentu yang berlangsung dalam waktu tertentu. Pelatihan pada umumnya diselenggarakan melalui peragaan menggunakan media dan peraktek. Warther dan Davis (1993: 313) mengemukakan bahwa program pelatihan ditentukan oleh identifikasi 
kebutuhan-kebutuhan dan sasaran latihan. Program pelatihan mungkin berupaya mengajarkan berbagai keterampilan tertentu, menyampaikan pengetahuan yang dibutuhkan dan mengubah sikap.

Berdasarkan uraian di atas dapat dikemukakan pelatihan (training) merupakan suatu proses pembelajaran dengan memberikan keterampilan tertentu yang berlangsung dalam waktu tertentu yang diselenggarakan melalui peragaan menggunakan media dan praktek.

Remiszowski (1981: 60-61) mengemukakan bahwa ada 3 hal yang sangat esensial perlu diperhatikan dalam kaitannya dengan metodologi pelatihan, yaitu: (1) perencanaan pelatihan; (2) metode pelatihan; dan (3) media pelatihan. Rencana pelatihan disusun berdasarkan kurikulum pelatihan yang mengacu pada pengembangan kemampuan (komptensi) para peserta pelatihan tersebut. Metode pelatihan adalah cara-cara dalam teknik komunikasi yang digunakan oleh pelatih dalam menyajikan dan melaksanakan proses pembelajaran. Media pelatihan adalah berbagai alat dan teknik komunikasi sebagai alat dalam pelaksanaan proses pembelajaran, baik oleh pelatih maupun oleh peserta pelatihan.

Selanjutnya Joice Bruce dan Wil Marsha (1980: 62-63) mengemukakan bahwa pemilihan dan penggunaan metode dan media komunikasi pembelajaran dalam pelatihan tersebut perlu mempertimbangkan hal-hal sebagai berikut: (1) Tujuan pelatihan, baik tujuan umum maupun tujuan khusus yang menitikberatkan pada perubahan perilaku peserta pelatihan. Pelatihan tersebut diharapkan mampu menghasilkan perilaku yang dapat mengubah masyarakat dari tidak tahu, tidak memahami menjadi lebih terampil dalam melakukan pekerjaan sesuai dengan apa yang telah dilatihkan kepada mereka; (2) Bahan yang akan disajikan berupa materi pelajaran yang disusun dalam Garis-garis Besar Program Pengajaran (GBPP). Bahan atau materi pelatihan harus diperhitungkan karakteristik pengetahuan, kondisi ekonomi dan sebagainya dari peserta pelatihan yang akan dilatih; (3) Waktu disesuaikan dengan alokasi waktu yang telah ditentukan. Waktu merupakan faktor yang harus diperhatikan dalam pelaksanaan pelatihan,; tidak tertarik pada kegiatan-kegiatan yang lain dari pada aktivitasnya sendiri yang sementara dilakukan; (4) Kemampuan pelatih menggunakan metode dan media komunikasi dalam proses pembelajaran. Kemampuan pelatih yang dimaksudkan di sini adalah kecakapan pelatih mengorganisasi dan mengolah materi pelatihan dengan unsur-unsur lain yang terkait dalam proses pelaksanaan pelatihan yang dilakukan; (5) Tingkat kemampuan peserta khususnya perilaku awal. Tingkat kemampuan awal dari peserta merupakan kompetensi dasar yang dimiliki oleh peserta seperti: pengetahuan, tingkat pendidikan dan sebagainya yang berkaitan dengan apa yang hendak dilatihkan kepada mereka.

Menurut Roblyer dan Doering (2010: 32-60) sesuatu inovasi teknologi yang akan dilatihkan kepada masyarakat sebaiknya memperhitungkan halhal sebagai berikut: (1) merefleksikan isi pengetahuan masyarakat tentang teknologi yang akan diterapkan; (2) menentukan keuntungan dari hasil inovasi itu; (3) memutuskan tujuan dan pengukuran/penilaian; (4) Mendesain langkah-langkah yang dilakukan untuk mengembangkan inovasi tersebut; (5) menyediakan lingkungan pelatihan; (6) melakukan evaluasi dan revisi.

Jadi, media pelatihan diartikan sebagai alat atau instrumen yang digunakan dalam membuka wawasan (aspek kognitif) berupa tiga dimensi (maket) dan grafis (gambar) yang dipahami supaya mau berbuat (afektif) dan dihayati (psikomotorik). Jadi, media pelatihan yang dapat digunakan dalam keterampilan pembuatan sanitasi rumah tinggal berwawasan lingkungan di antaranya: (a) media tiga dimensi (media maket); dan (b) media grafis (media gambar).

\section{a. Media Tiga Dimensi (Media Maket)}

Teori John M. Keller dalam Reizer Robert A. dan John V. Dempsey (2007: 82-88) tentang ARCS model: yaitu $\mathrm{A}=$ Attention (perhatikan) yaitu: membangun perhatian seseorang untuk melihat sesuatu, $\mathrm{R}=$ Relevance (keinginan) yaitu: setelah diperhatikan apa yang diperlihatkan timbul keinginan tentang apa yang dilihat dengan yang dimiliki, $\mathrm{C}=$ Confidence (keyakinan) yaitu: setelah melihat lalu mengaitkan dengan apa yang dimiliki sehingga timbul keyakinan terhadap apa yang dilihat, dan $\mathrm{S}=$ Satisfaction (kepuasan) yaitu: kalau sudah diperhatikan dan mengaitkan antara yang dilihat dengan yang dimiliki dan kemudian menyakini dan percaya adanya manfaat dari sesuatu yang dilihat maka lahirlah kepuasan.

Pelatihan dengan menggunakan media visual dalam hal ini media tiga dimensi (media maket) sejalan dengan ARCS model yaitu: memperhatikan suatu obyek (media visual) dan mengaitkan antara yang dilihat dengan yang dimiliki, kemudian meyakini dan percaya adanya manfaat lahirlah kepuasan. Dari keempat proses tersebut lahirlah kesadaran dalam diri seseorang tentang potensi yang dimilikinya untuk melakukan hal yang serupa.

Teori Gestalt dalam Lohr Linda (2003: 241), menyebutkan bahwa keseluruhan lebih bermakna dari pada bagian-bagiannya. Jadi dikaitkan dalam konsep sanitasi lingkungan masih bersifat abstrak sehingga dibutuhkan upaya dan sarana untuk menkonkretkannya. Artinya konsep sanitasi 
lingkungan yang dipahami secara abstrak dan hanya sebahagian setelah melihat konsep dalam bentuk tiga dimensi (bentuk maket). Akhirnya dapat dipahami secara total dan pemahamannya dapat menjadi konkret atau dapat dipahami secara keseluruhan.

Menurut Miarso (2009: 464-465) bahwa model (media maket) merupakan reproduksi yang kelihatannya sama tetapi biasanya diperkecil atau diperbesar dalam skala tertentu dan mempunyai bagian-bagian sesuai dengan pola benda yang sesungguhnya. Antonie Predok (1995: 27) dalam dunia arsitektur, maket adalah model/miniatur atau tiruan dari objek bangunan yang diperkecil dengan skala tertentu.

Teori Elgar Dale dalam Seels dan Richey (1994: 14) mengembangkan kerucut pengalaman menjadi sepuluh bagian. Kerucut ini sekaligus menggambarkan tingkat kekonkretan dan keabstrakan metode pengajaran dan bahan pembelajaran tersebut. Lapisan paling dasar adalah: (1) Direct purposeful experience yaitu: pengalaman langsung; (2) Contrived experiences yaitu: pengalaman buatan (tiruan model/maket); (3) Dramatic participation (dramatisasi); (4) Demonstrations (demonstrasi); (5) Field trips (karya wisata); (6) Exhibits (pameran); (7) Motion picture (gambar hidup); (8) Radio recordings still pictures (radio rekaman, gambar mati); (9) Visual symbols (lambang visual); (10) Verbal symbols lambang verbal (kata-kata).

Dari teori tersebut dapat dipahami bahwa pelatihan menggunakan media tiga dimensi atau benda tiruan (media maket) merupakan media yang dapat digunakan dalam pelatihan keterampilan membuat sanitasi rumah tinggal berwawasan lingkungan karena pengalaman melihat benda buatan atau tiruan (media maket) akan lebih mudah memahami benda yang akan dibuat, hanya diperkecil dalam skala tertentu dan mempunyai bagian-bagian sesuai dengan pola benda yang sesungguhnya.

Fairweather, Lesle, Metric (1987: 57) mengemukakan bahwa media maket selain menarik karena merupakan miniatur dari sebuah bangunan dengan skala kecil, juga memiliki fungsi sebagai berikut : (1) Mempertegas dan menjelaskan suatu gambar rancangan bangunan dalam bentuk tiga dimensi sesuai aslinya. Namun, dalam skala kecil sehingga dapat terlihat jelas dan dapat dipahami oleh orang awam yang berpendidikan rendah; (2) Sebagai bagian dari proses desain bagi seorang arsitek dengan membuat media maket terlebih dahulu sehingga memudahkan ekpolorasi bentuk terhadap suatu rancangan; (3) Memudahkan orang lain untuk melihat ruang dalam (interior).

Jadi, media tiga dimensi (media maket) adalah: media pembelajaran yang merupakan model/miniatur dari objek/benda yang kelihatannya sama tetapi diperkecil atau diperbesar dalam skala tertentu. Dengan demikian, dapat diartikan bahwa media tiga dimensi (media maket) adalah: alat nyata yang berbentuk model tiga dimensi yang digunakan dalam pelatihan untuk dihayati dan didalami maknanya.

\section{b. Media Grafis (Media Gambar)}

Menurut Piaget dalam Singer dan Revenson (1996: 20) pertumbuhan intelektual dapat melewati tiga tahap yakni: (1) asimilasi yaitu melibatkan pengetahuan baru dengan struktur pengetahuan sebelumnya; (2) akomodasi yaitu perubahan struktur pengetahuan yang sudah ada sebelumnya untuk mengakomodasi hadirnya pengetahuan baru, penyatuan antara perasaan asimilasi dan akomodasi dapat membentuk schema; (3) equilibration yaitu penggabungan antara asimilasi dan akomodasi lalu ada perubahan baru lagi atau keseimbangan antara pribadi dan lingkungannya. Dikaitkan dengan penggunaan media grafis (media gambar) dalam pelatihan membuat sanitasi berwawasan lingkungan yaitu masyarakat nelayan mampu berbuat sesuatu dan pernah mendapatkan pengetahuan sebelumnya memiliki kecenderungan dapat lebih mengakomodasi hadirnya pengetahuan baru. Mereka dapat lebih cepat menangkap serta membaca materi pelatihan dengan menggunakan media grafis (media gambar) karena sudah pernah mendapatkan pengetahuan gambar sebelumnya dan dipadukan dengan pengetahuan gambar yang baru.

Menurut Miarso media grafis (media gambar) adalah media yang dibuat melalui proses gambar digunakan untuk mempermudah penerimaan pesan pada masyarakat (peserta). Sedangkan Bruner (1966: 10-11) mengemukakan bahwa ada tiga tingkatan utama modul belajar, yaitu: (1) pengalaman langsung (enactive); (2) pengalaman pictorial/gambar (iconic) dan pengalaman abstrak (symbolic). Pengalaman langsung adalah mengerjakan, misalnya: Arti kata "sanitasi" dipahami langsung membuat "sanitasi". Pada tingkatan kedua yang diberi label iconic (gambar atau image), kata "sanitasi" dipelajari melaui gambar, meskipun peserta belum pernah membuat sanitasi mereka dapat mempelajari dan memahaminya dari gambar. Selanjutnya pada tingkatan ketiga pengalaman abstrak (simbol) yaitu peserta membaca atau mendengar kata sanitasi dan mencoba mencocokkannya dengan pengalaman membuat sanitasi. Ketiga tingkat pengalaman ini saling berinteraksi dalam upaya memperoleh pengalaman (pengetahuan, keterampilan, atau sikap) yang baru. Dapat dikatakan bahwa media gambar digunakan untuk mempermudah penerimaan pesan kepada masyarakat (peserta), dan apabila mengalaman 
melihat gambar digabung dengan pengalaman langsung serta pengalaman absrak berinteraksi akan menghasilkan pengetahuan, keterampilan, dan sikap yang baru. Kemp dan Smellie (1989: 105) mengatakan bahwa prinsip desain media grafis harus mencakup: simpel, kesatuan, penekanan, dan keseimbangan

Media grafis berfungsi menyalurkan pesan dan sumber ke penerima pesan. Saluran yang dipakai menyangkut indera penglihatan, pesan yang disampaikan dituangkan ke dalam simbol-simbol komunikasi visual. Media gambar adalah media yang paling umum dipakai, dan merupakan bahasa yang umum, yang dapat dipahami. Pepatah cina mengatakan bahwa sebuah gambar berbicara lebih banyak dari pada seribu kata.

Dengan demikian, sesuai teori dan penjelasan tersebut di atas dapat diartikan bahwa dalam pembuatan media grafis harus dibuat secara simpel dan jelas, mempunyai kesatuan antara gambar satu dengan yang lainnya, mempunyai penekanan pada objek yang akan dijelaskan, dan mempunyai keseimbangan dalam tata letak gambar.

Menurut Hakim dan Sediadi (2006:1) tujuan dari penggunaan media grafis adalah memberikan gambaran tentang gagasan atau rancangan dari perancang sesuai dengan kebutuhan pengguna. Sadiman, dkk. (1986: 29-31) kelebihan media gambar dapat dijelaskan sebagai berikut: (1). sifatnya konkret; (2). gambar dapat mengatasi batasan ruang dan waktu; (3). media gambar dapat mengatasi keterbatasan pengamatan kita, (4). media gambar dapat memperjelas suatu masalah.

Media grafis (media gambar) merupakan media pelatihan yang berbentuk gambar dengan skala tertentu dari objek/benda untuk memberikan gambaran tentang gagasan atau rancangan sesuai dengan kebutuhan pengguna. Dengan demikian, dapat diartikan bahwa media grafis (media gambar) adalah: alat dalam bentuk gambar dengan skala dan ukuran tertentu yang digunakan dalam pelatihan untuk dihayati dan didalami maknanya.

Jadi, media pelatihan menggunakan media tiga dimensi (media maket) dan media grafis (media gambar) dapat digunakan menyampaikan gagasan dalam hal keterampilan pembuatan sanitasi rumah tinggal berwawasan lingkungan yaitu pembuatan dan pemasangan: (1) tiang rangka jamban keluarga model panggung; (2) lantai, dinding dan atap jamban keluarga model panggung,; (3) bak penampungan tinja (septictank) dari bius beton dan instalasi pemipaannya; (4) drainase (comberan) untuk rumah panggung; (5) saringan penjernihan air bersih; dan (6) tempat sampah rumah tangga.

\section{Tingkat Pendidikan}

Salah satu wadah untuk menyelenggarakan pendidikan menurut Inkeles (1992: 100) adalah sekolah yakni sebagai tempat berlangsungnya pendidikan formal dan proses sosialisasi. Pendidikan sebagai salah satu bekal dalam meraih kehidupan yang bahagia karena dengan pendidikan menurut Keith orang akan memahami agama, politik, kesehatan, dan ideologi. Segall (1999: 78-90) pendidikan menurut dimensi formal dan informal dibagi atas kategori: (1) pendidikan formal; (2) pendidikan nonformal; dan (3) pendidikan informal. Pendidikan yang diperoleh dari sekolah atau schooling dikategorikan sebagai pendidikan formal. Pendidikan yang diperoleh dari luar sekolah atau out-of-school education dikategorikan sebagai pendidikan nonformal dan pendidikan yang diperoleh dari lingkungan keluarga sebagai tradisional education dikategorikan sebagai pendidikan informal. Kehidupan dalam lingkungan keluarga maupun yang berlangsung dalam hubungan sosial dengan masyarakat sekitar merupakan lingkungan belajar yang dapat mempengaruhi perubahan perilakau seseorang. Demikian pula halnya dengan sumber pengetahuan yang diperoleh dari sekolah. Paul Vogt (1977: 61-62) peran pendidikan formal di sekolah begitu luas mencakup aspek pengetahuan, keterampilan, terutama sosialiasi dari nilai-nilai sikap dalam kehidupan bermasyarakat. Tingkat pendidikan seseorang dapat diukur dari pendidikan yang diperolehnya dari sekolah. Tingkat pendidikan menurut Good dan Brophy (1990: 584) diukur dari lamanya seseorang mengalami proses pendidikan secara formal di sekolah. Tingkat pendidikan dalam skala status sosial ekonomi menurut Hopkins, Stanley (1981: 20) dibagi dalam 7 tingkat yaitu; (1) bersekolah dibawah 7 tahun, (2) bersekolah selama 7 - 9 tahun, (3) bersekolah 10 - 11 tahun, (4) tamat sekolah menengah umum, (5) tamat D3, (6) tamat S1 peguruan tinggi, dan (7) professional (master, doktor) .

Menurut Inkeles dan Smith (1992: 100), mereka yang lebih lama mengalami pendidikan di sekolah bersifat lebih terbuka terhadap ide-ide baru dan pengalaman baru, mereka lebih menghargai ilmu dan siap menerima perubahan. Demikian pula menurut Hopkins (1981: 457) dengan rata-rata tingkat pendidikan yang tinggi dapat digunakan untuk menginterpretasi profil seseorang. Seseorang cenderung lebih bersifat tebuka terhadap informasi, dan cepat menerima inovasi dari pada mereka dengan tingkat pendidikan rendah.

Vogt, W. Paul (1997: 61) mengemukakan pendidikan yang diperoleh dari sekolah dapat digunakan mengukur tingkat pendidikan seseorang. 
Tingkat pendidikan diukur dari lamanya seseorang terlibat dalam proses pendidikan secara formal di sekolah. Gardner dan Stern (1996: 74) mengemukakan bahwa pendidikan dapat berubah sikap dan kepecayaan terhadap lingkungan.

Jadi, tingkat pendidikan yang dimasud dalam penelitian ini adalah: proses perubahan yang dipengaruhi oleh waktu dan jenjang (pendidikan formal). Lamanya mengalami pendidikan formal diukur dengan skala bilangan jumlah tahun yang dialami masyarakat nelayan dalam mengikuti pendidikan formal di sekolah. Hal ini dapat dijelaskan sebagai berikut: SD (sederajat) kelas I diberi skor 1, kelas II diberi skor 2, dan seterusnya sampai kelas VI/tamat diberi skor 6, SMP (sederajat) kelas I diberi skor 7, kelas II diberi skor 8, dan kelas III/tamat diberi skor 9. SMA (sederajat) kelas I diberi skor 10, kelas II diberi skor 11, dan kelas III/tamat diberi skor 12. Dengan demikian, pendidikan rendah (SD - SMP) 3 - 9 tahun (pendidikan dasar 9 tahun), sedangkan pendidikan tinggi (SMA) 10 - 12 tahun (pendidikan menengah) mengalami pendidikan formal.

\section{Kerangka Berpikir}

\section{Perbedaan Keterampilan Pem-buatan Sanitasi Rumah Tinggal Berwawasan Lingkungan antara Kelompok Masyarakat Nelayan yang Mengikuti Pelatihan Menggunakan Media Tiga Dimensi (Media Maket) dengan yang Mengikuti Pelatihan Menggunakan Media Grafis (Media Gambar).}

Pelatihan adalah penyampaian informasi dan inovasi teknologi tertentu yang bertujuan meningkatkan keterampilan serta dampak yang ditimbulkan oleh suatu inovasi. Dengan demikian, keterampilan pembuatan sanitasi rumah tinggal berwawasan lingkungan pada perinsipnya adalah proses kognitif dan psikomotorik. Ada enam kegiatan pokok yang harus dilakukan dalam rangkaian pembuatan sanitasi rumah tinggal berwawasan lingkungan dan tiap-tiap kegiatan pokok tersebut dinilai keterampilan peserta dalam hal pekerjaan persiapan, proses dan pencapaian hasil. Kegiatan pokok tersebut adalah: (1) pelatihan pembuatan dan pemasangan tiang rangka jamban keluarga model panggung; (2) pelatihan pembuatan dan pemasangan lantai, dinding, dan atap jamban keluarga model panggung; (3) pelatihan pemasangan septictank buis beton dan instalasi pemipaannya; (4) pelatihan pembuatan dan pemasangan drainase untuk rumah panggung; (5) pelatihan pembuatan dan pemasangan saringan penjernihan air bersih; (6) pelatihan pembuatan dan pemasangan tempat sampah rumah tangga. Keterampilan persiapan adalah keterampilan yang dapat diperagakan oleh masyarakat nelayan dalam hal mempersiapkan alat dan bahan yang digunakan dalam pembuatan sanitasi rumah tinggal berwawasan lingkungan. Keterampilan proses adalah keterampilan yang dapat diperagakan oleh masyarakat nelayan dalam hal proses kerja dalam pembuatan sanitasi rumah tinggal berwawasan lingkungan. Keterampilan hasil adalah pencapaian tujuan atau hasil secara optimal yang diperoleh masyarakat nelayan setelah seluruh rangkaian mulai dari pekerjaan persiapan, proses sampai pada pencapaian tujuan akhir dari kegiatan pembuatan sanitasi rumah tinggal berwawasan lingkungan yang dilakukan. Sebagai indikator dari ketiga macam keterampilan pembuatan sanitasi rumah tinggal berwawasan lingkungan ini adalah terbentuknya keterampilan masyarakat nelayan dalam melakukan atau mengerjakan seluruh rangkaian dari ketiga kategori keterampilan berdasarkan konsep-konsep keterampilan yang telah ditetapkan serta memperlihatkan media pelatihan.

Apabila keterampilan masyarakat nelayan dapat terbentuk dengan baik, kemudian masyarakat nelayan tersebut diharapkan mampu dan bersedia menerima inovasi sanitasi rumah tinggal berwawasan lingkungan, maka proses adaptasi inovatif masyarakat nelayan menjadi cepat. Agar keterampilan dapat terbentuk dengan baik untuk menunjang pembentukan perilaku yang lebih positif terhadap adopsi teknologi pembuatan sanitasi rumah tinggal berwawasan lingkungan diperlukan media pelatihan yang relevan dengan karakteristik masyarakat nelayan yang bersangkutan.

Keterampilan dapat terbentuk dengan baik, serta menunjang pembentukan perilaku yang lebih positif, diperlukan media pelatihan yang relevan dengan karakteristik masyarakat nelayan yang bersangkutan.

Apabila melihat sifat materi keterampilan pembuatan sanitasi rumah tinggal berwawasan lingkungan, masyarakat nelayan cenderung bersifat teknis dan praktis Diduga pelatihan menggunakan media tiga dimensi (media maket) memiliki hasil yang lebih baik daripada pelatihan menggunakan media grafis (media gambar). Dengan pelatihan menggunakan media tiga dimensi (media maket). Masyarakat nelayan pada saat pelatihan dapat melihat secara nyata apa yang akan dibuat dengan melihat media tiga dimensi (media maket) yang sama dengan bentuk aslinya yang akan dibuat. Mereka hanya yang membedakan dalam bentuk miniatur dengan skala diperkecil. Adapun pelatihan menggunakan media grafis (media gambar), masyarakat nelayan pada saat pelatihan dapat melihat secara abstrak apa yang akan dibuat. Mereka melihat dalam bentuk gambar. 
Dari deskripsi tersebut di atas pelatihan menggunakan media tiga dimensi (media maket) dan pelatihan yang menggunakan media grafis (media gambar) memiliki keunggulan-keunggulan masingmasing. Namun, dilihat dari tujuan pelatihan keterampilan pembuatan sanitasi rumah tinggal berwawasan lingkungan pada masyarakat nelayan, dan substansi materi yang memiliki karakteristik abstrak dan konkret (nyata), maka pelatihan keterampilan menggunakan media tiga dimensi (media maket) memberikan kesan yang lebih tinggi dibandingkan media grafis (media gambar).

\section{Pengaruh Interaksi antara Media Pelatihan dan Tingkat Pendidikan terhadap Keterampilan Masyarakat Nelayan dalam Pembuatan Sanitasi Rumah Tinggal Berwawasan Lingkungan.}

Terdapat berbagai faktor yang mempengaruhi keberhasilan suatu pelatihan, yatu terbentuknya keterampilan pembuatan sanitasi rumah tinggal berwawasan lingkungan. Faktor-faktor tersebut dapat berasal dari dalam dan dari luar diri masyarakat nelayan peserta pelatihan itu. Salah satu di antara faktor dari dalam diri masyarakat nelayan peserta pelatihan tersebut adalah tingkat pendidikan, sedangkan faktor yang berasal dari luar adalah media pelatihan.

Apabila dengan melihat karakteristik materi yang disajikan, maka materi keterampilan tentang pembuatan sanitasi rumah tinggal berwawasan lingkungan bekaitan dengan konsep, prinsip, dan prosedur yang harus dikuasai masyarakat nelayan sebagai peserta pelatihan. Oleh karena itu, hal tersebut menjadi suatu hal yang perlu dipertimbangkan dalam memilih media pelatihan yang akan digunakan. Pelatihan menggunakan media tiga dimensi (media maket) dan pelatihan menggunakan media grafis (media gambar) dianggap efektif membentuk keterampilan bagi masyarakat nelayan. Pada pelatihan menggunakan media tiga dimensi (media maket), masyarakat nelayan dapat melihat secara nyata apa yang akan dibuat dengan melihat media tiga dimensi (media maket) yang sama dengan bentuk aslinya yang akan dibuat dengan skala kecil, hanya yang membedakan dalam bentuk miniatur. Adapun pelatihan yang menggunakan media grafis (media gambar), masyarakat nelayan pada saat pelatihan hanya melihat secara abstrak apa yang akan dibuat. Pelatihan menggunakan media grafis (media gambar) peserta melihat dalam bentuk gambar.

Apabila dihubungkan dengan tingkat pendidikan masyarakat nelayan, peserta pelatihan relatif berbeda dan memiliki karakteristik yang berbeda pula.
Masyarakat nelayan yang berpendidikan tinggi dapat dipastikan mereka memiliki pengetahuan dasar tentang pembuatan sanitasi rumah tinggal berwawasan lingkungan yang cukup memadai untuk dapat menganalisis dan menerjemahkan setiap informasi baru yang diterima dari pelatih (instruktur). Selain itu mereka cenderung memiliki keterbukaan serta cepat menerima informasi dari pelatih, baik yang bersifat faktual maupun yang bersifat konseptual. Sebaliknya masyarakat nelayan yang memiliki tingkat pendidikan yang rendah biasanya cenderung bersifat tertutup terhadap perubahan dan sulit menerima informasi baru yang bersifat abstrak serta cenderung menerima suatu inovasi setelah melihat keberhasilan yang dicapai orang lain di lapangan.

Perbedaan karakteristik masing-masing kelompok masyarakat nelayan peserta pelatihan ini dituntut pula adanya perbedaan perlakuan di antara kedua kelompok tersebut. Bagi masyarakat nelayan yang berpendidikan tinggi mengikuti pelatihan menggunakan media grafis (media gambar) dapat lebih tinggi keterampilan mereka dibandingkan menggunakan media tiga dimensi (media maket) dalam pembuatan sanitasi rumah tinggal berwawasan lingkungan. Sebaliknya bagi masyarakat nelayan yang berpendidikan rendah mengikuti pelatihan menggunakan media tiga dimensi (media maket) dapat lebih tinggi keterampilan mereka dibandingkan menggunakan media grafis (media gambar) tentang pembuatan sanitasi rumah tinggal berwawasan lingkungan.

Oleh karena itu, diduga bahwa pelatihan menggunakan media tiga dimensi (media maket) sangat efektif untuk membentuk keterampilan masyarakat nelayan yang secara rata-rata tingkatan pendidikannya masih rendah dalam pembuatan sanitasi rumah tinggal berwawasan lingkungan.

Berdasarkan dasar-dasar pemikiran seperti yang telah dikemukakan di atas, maka diduga kuat terdapat pengaruh interaksi antara media pelatihan dengan tingkat pendidikan terhadap peningkatan atau terbentuknya keterampilan masyarakat nelayan tentang pembuatan sanitasi rumah tinggal berwawasan lingkungan

\section{Perbedaan Keterampilan Pembuatan Sanitasi Rumah Tinggal Berwawasan Lingkungan antara Masyarakat Nelayan yang Berpendidikan Tinggi Mengikuti Pelatihan Menggunakan Media Tiga Dimensi (Media Maket) dengan yang Menggunakan Media Grafis (Media Gambar).}

Keterampilan pembuatan sanitasi rumah tinggal berwawasan lingkungan adalah hasil belajar setelah 
masyarakat nelayan peserta pelatihan menerima bebagai pengalaman dalam peristiwa belajar tertentu pada setiap tahapan materi pelatihan yang diberikan. Pengoptimalan proses belajar dalam setiap peristiwa belajar dalam kegiatan pelatihan diperlukan suatu media yang sesuai dengan karakteristik inovasi dari tiap individu masyarakat nelayan peserta pelatihan dalam menyerap materi pelatihan yang diberikan. Tingkat pendidikan merupakan salah satu hal yang diduga ikut berpengaruh terhadap kemampuan masyarakat nelayan untuk dapat menyerap materi pelatihan yang disajikan.

Dalam melakukan pelatihan, seseorang pelatih (instruktur) dituntut terlebih dahulu mengetahui karakteristik peserta pelatihan, yakni: dari segi usia, tingkat pendidikan, dan pengetahuan dasar (kompetensi) yang dimilikinya serta karakteristikkarakteristik lainnya yang diperkirakan ikut berpengaruh terhadap pencapaian hasil pembelajaran yang dilakukan padanya. Berdasarkan karakeristik yang diketahuinya tersebut, pelatih (instruktur) menyeleksi dan menetapkan media yang hendak digunakan dalam pelaksanaan pelatihan tersebut.

Apabila melihat sifat materi keterampilan tentang pembuatan sanitasi rumah tinggal berwawasan lingkungan pada masyarakat nelayan cenderung bersifat teknis dan praktis. Adapun penggunaan media pelatihan tiga dimensi (media maket) pada masyarakat nelayan dapat melihat secara nyata, untuk mengetahui ukuran yang akan dibuat, dapat mengukur langsung media tiga dimensi (media maket) dengan skala yang ditentukan, karena media tiga dimensi (media maket) tersebut sama dengan bentuk aslinya dengan skala, hanya yang membedakan dalam bentuk ukuran kecil. Sedangkan pelatihan menggunakan media grafis (media gambar) daam pembuatan sanitasi rumah tingal berwawasan lingkungan pada masyarakat nelayan dapat membaca gambar kerja dan lebih cepat menangkap benda kongkritnya yang akan dibuat karena dapat membaca ukuran-ukuran serta keterangan/notasi pada media grafis (media gambar).

Berdasarkan pemikiran ini, maka diduga bahwa keterampilan pembuatan sanitasi rumah tinggal berwawasan lingkungan secara keseluruhan masyarakat nelayan yang memiliki tingkat pendidikan tinggi mengikuti pelatihan menggunakan media grafis (media gambar) lebih tinggi dari pada menggunakan media tiga dimensi (media maket), karena masyarakat nelayan yang berpendidikan tinggi dapat memadukan antara pengetahuan gambar yang pernah didapatkan sebelumnya (kompetensi yang dimilikinya) dengan pengetahuan gambar yang didapatkan pada saat pelatihan. Mereka dapat membaca gambar baik ukuran-ukurannya maupun keterangan/notasi yang ada pada media grafis (media gambar). Selain itu, mereka terbuka terhadap ide dan pengalaman baru sehingga lebih cepat menangkap benda konkretnya yang akan dibuat.

\section{Perbedaan Keterampilan Pembuatan Sanitasi Rumah Tinggal Berwawasan Lingkungan antara Masyarakat Nelayan yang Berpendidikan Rendah Mengikuti Pelatihan Menggunakan Media Tiga Dimensi (Media Maket) dengan yang Menggunakan Media Grafis (Media Gambar).}

Keterampilan pembuatan sanitasi rumah tinggal berwawasan lingkungan adalah hasil belajar setelah masyarakat nelayan peserta pelatihan menerima bebagai pengalaman dalam peristiwa belajar tertentu pada setiap tahapan materi pelatihan yang diberikan. Untuk mengoptimalkan proses belajar dalam setiap peristiwa belajar dalam kegiatan pelatihan diperlukan suatu media pelatihan yang sesuai dengan karakteristik inovasi dari tiap individu masyarakat nelayan sebagai peserta pelatihan. Apabila diterapkan mampu menyerap materi pelatihan yang diberikan. Tingkat pendidikan merupakan salah satu hal yang diduga ikut berpengaruh terhadap kemampuan masyarakat nelayan untuk menyerap materi pelatihan yang disajikan.

Dalam melakukan pelatihan, seorang pelatih (instruktur) dituntut mengetahui karakteristik peserta pelatihan, yakni dari segi usia, tingkat pendidikan, dan pengetahuan dasar (kompetensi) yang dimilikinya serta karakteristik-karakteristik lainnya yang diperkirakan ikut berpengaruh terhadap pencapaian hasil pembelajaran. Berdasarkan karakeristik yang diketahuinya tersebut, pelatih (instruktur) menyeleksi dan menetapkan media yang hendak digunakan dalam pelaksanaan pelatihan tersebut.

Apabila melihat sifat materi keterampilan pembuatan sanitasi rumah tinggal berwawasan lingkungan, masyarakat nelayan yang berpendidikan rendah cenderung bersifat teknis dan praktis.Tingkat pendidikan masyarakat yang rendah menyebabkan keterbatasan keterampilan membaca gambar, sehingga mereka mengalami kesulitan membaca ukuran-ukuran gambar serta notasi gambar. Selain itu mereka kurang terbuka terhadap ide dan pengalaman baru. Mereka lebih percaya terhadap suatu inovasi apabila telah melihat keberhasilan orang lain di lapangan.

Pelatihan keteramplan menggunakan media tiga dimensi (media maket), masyarakat nelayan dapat melihat secara nyata (konkret) apa yang akan dibuat pada saat pelatihan. Dengan melihat media tiga dimensi (media maket) yang sama dengan bentuk aslinya yang akan dibuat, hanya yang membedakan skala kecil (miniatur). Jadi, keterampilan pembuatan 
sanitasi rumah tinggal berwawasan lingkungan akan mudah dicapai. Adapun dengan melalui pelatihan yang menggunakan media grafis (media gambar), masyarakat nelayan berpendidikan rendah pada saat pelatihan hanya dapat melihat secara abstrak apa yang akan dibuat.

Berdasarkan pemikiran ini, maka diduga bahwa keterampilan pembuatan sanitasi rumah tinggal berwawasan lingkungan secara keseluruhan dari masyarakat nelayan yang berpendidikan rendah bila mengikuti pelatihan menggunakan media tiga dimensi (media maket) akan lebih tinggi daripada menggunakan media grafis (media gambar).

\section{Hipotesis Penelitian}

Berdasarkan kerangka teori serta kerangka berpikir yang telah dikemukakan di atas, hipotesis penelitian dapat dirumuskan sebagai berikut:

1. Keterampilan pembuatan sanitasi rumah tinggal berwawasan lingkungan pada kelompok masyarakat nelayan yang mengikuti pelatihan menggunakan media tiga dimensi (media maket) lebih tinggi daripada kelompok masyarakat nelayan yang mengikuti pelatihan menggunakan media grafis (media gambar).

2. Terdapat pengaruh interaksi antara media pelatihan dan tingkat pendidikan terhadap keterampilan masyarakat nelayan tentang pembuatan sanitasi rumah tinggal berwawasan lingkungan.

3. Keterampilan pembuatan sanitasi rumah tinggal berwawasan lingkungan pada kelompok masyarakat nelayan yang berpendidikan tinggi yang mengikuti pelatihan menggunakan media grafis (media gambar) akan lebih tinggi dari pada peserta yang mengikuti pelatihan menggunakan media tiga dimensi (media maket).

4. Keterampilan pembuatan sanitasi rumah tinggal berwawasan lingkungan pada kelompok masyarakat nelayan yang berpendidikan rendah dan mengikuti pelatihan menggunakan media tiga dimensi (media maket) lebih tinggi daripada yang mengikuti pelatihan menggunakan media grafis (media gambar).

\section{METODOLOGI PENELITIAN}

Penelitian ini bertujuan: (1) Mengetahui perbedaan keterampilan pembuatan sanitasi rumah tinggal berwawasan lingkungan antara kelompok masyarakat nelayan yang mengikuti pelatihan menggunakan media tiga dimensi (media maket) dengan kelompok masyarakat nelayan yang mengikuti pelatihan menggunakan media grafis (media gambar); (2) Mengetahui interaksi antara media pelatihan dan tingkat pendidikan terhadap keterampilan masyarakat nelayan tentang pembuatan sanitasi rumah tinggal berwawasan lingkungan; (3) Mengetahui perbedaan keterampilan pembuatan sanitasi rumah tinggal berwawasan lingkungan antara kelompok masyarakat nelayan berpendidikan tinggi yang mengikuti pelatihan menggunakan media tiga dimensi (media maket) dengan kelompok masyarakat nelayan yang Adapun pelatihan menggunakan media grafis (media gambar), masyarakat nelayan pada saat pelatihan dapat melihat secara abstrak apa yang akan dibuat. Mereka melihat dalam bentuk gambar.

Dari deskripsi tersebut di atas pelatihan menggunakan media tiga dimensi (media maket) dan pelatihan yang menggunakan media grafis (media gambar) memiliki keunggulan-keunggulan masingmasing. Namun, dilihat dari tujuan pelatihan keterampilan pembuatan sanitasi rumah tinggal berwawasan lingkungan pada masyarakat nelayan, dan substansi materi yang memiliki karakteristik abstrak dan konkret (nyata), maka pelatihan keterampilan menggunakan media tiga dimensi (media maket) memberikan kesan yang lebih tinggi dibandingkan media grafis (media gambar).

\section{Pengaruh Interaksi antara Media Pelatihan dan Tingkat Pendidikan terhadap Keterampilan Masyarakat Nelayan dalam Pembuatan Sanitasi Rumah Tinggal Berwawasan Lingkungan.}

Terdapat berbagai faktor yang mempengaruhi keberhasilan suatu pelatihan, yatu terbentuknya keterampilan pembuatan sanitasi rumah tinggal berwawasan lingkungan. Faktor-faktor tersebut dapat berasal dari dalam dan dari luar diri masyarakat nelayan peserta pelatihan itu. Salah satu di antara faktor dari dalam diri masyarakat nelayan peserta pelatihan tersebut adalah tingkat pendidikan, sedangkan faktor yang berasal dari luar adalah media pelatihan.

Apabila dengan melihat karakteristik materi yang disajikan, maka materi keterampilan tentang pembuatan sanitasi rumah tinggal berwawasan lingkungan bekaitan dengan konsep, prinsip, dan prosedur yang harus dikuasai masyarakat nelayan sebagai peserta pelatihan. Oleh karena itu, hal tersebut menjadi suatu hal yang perlu dipertimbangkan dalam memilih media pelatihan yang akan digunakan. Pelatihan menggunakan media tiga dimensi (media maket) dan pelatihan menggunakan media grafis (media gambar) dianggap efektif membentuk keterampilan bagi masyarakat nelayan. Pada pelatihan menggunakan media tiga dimensi (media maket), masyarakat nelayan dapat melihat secara nyata apa 
yang akan dibuat dengan melihat media tiga dimensi (media maket) yang sama dengan bentuk aslinya yang akan dibuat dengan skala kecil, hanya yang membedakan dalam bentuk miniatur. Adapun pelatihan yang menggunakan media grafis (media gambar), masyarakat nelayan pada saat pelatihan hanya melihat secara abstrak apa yang akan dibuat. Pelatihan menggunakan media grafis (media gambar) peserta melihat dalam bentuk gambar.

Apabila dihubungkan dengan tingkat pendidikan masyarakat nelayan, peserta pelatihan relatif berbeda dan memiliki karakteristik yang berbeda pula. Masyarakat nelayan yang berpendidikan tinggi dapat dipastikan mereka memiliki pengetahuan dasar tentang pembuatan sanitasi rumah tinggal berwawasan lingkungan yang cukup memadai untuk dapat menganalisis dan menerjemahkan setiap informasi baru yang diterima dari pelatih (instruktur). Selain itu mereka cenderung memiliki keterbukaan serta cepat menerima informasi dari pelatih, baik yang bersifat faktual maupun yang bersifat konseptual. Sebaliknya masyarakat nelayan yang memiliki tingkat pendidikan yang rendah biasanya cenderung bersifat tertutup terhadap perubahan dan sulit menerima informasi baru yang bersifat abstrak serta cenderung menerima suatu inovasi setelah melihat keberhasilan yang dicapai orang lain di lapangan.

Perbedaan karakteristik masing-masing kelompok masyarakat nelayan peserta pelatihan ini dituntut pula adanya perbedaan perlakuan di antara kedua kelompok tersebut. Bagi masyarakat nelayan yang berpendidikan tinggi mengikuti pelatihan menggunakan media grafis (media gambar) dapat lebih tinggi keterampilan mereka dibandingkan menggunakan media tiga dimensi (media maket) dalam pembuatan sanitasi rumah tinggal berwawasan lingkungan. Sebaliknya bagi masyarakat nelayan yang berpendidikan rendah mengikuti pelatihan menggunakan media tiga dimensi (media maket) dapat lebih tinggi keterampilan mereka dibandingkan menggunakan media grafis (media gambar) tentang pembuatan sanitasi rumah tinggal berwawasan lingkungan.

Oleh karena itu, diduga bahwa pelatihan menggunakan media tiga dimensi (media maket) sangat efektif untuk membentuk keterampilan masyarakat nelayan yang secara rata-rata tingkatan pendidikannya masih rendah dalam pembuatan sanitasi rumah tinggal berwawasan lingkungan.

Berdasarkan dasar-dasar pemikiran seperti yang telah dikemukakan di atas, maka diduga kuat terdapat pengaruh interaksi antara media pelatihan dengan tingkat pendidikan terhadap peningkatan atau terbentuknya keterampilan masyarakat nelayan tentang pembuatan sanitasi rumah tinggal berwawasan lingkungan

\section{Perbedaan Keterampilan Pembuatan Sanitasi Rumah Tinggal Berwawasan Lingkungan antara Masyarakat Nelayan yang Berpendidikan Tinggi Mengikuti Pelatihan Menggunakan Media Tiga Dimensi (Media Maket) dengan yang Menggunakan Media Grafis (Media Gambar).}

Keterampilan pembuatan sanitasi rumah tinggal berwawasan lingkungan adalah hasil belajar setelah masyarakat nelayan peserta pelatihan menerima bebagai pengalaman dalam peristiwa belajar tertentu pada setiap tahapan materi pelatihan yang diberikan. Pengoptimalan proses belajar dalam setiap peristiwa belajar dalam kegiatan pelatihan diperlukan suatu media yang sesuai dengan karakteristik inovasi dari tiap individu masyarakat nelayan peserta pelatihan dalam menyerap materi pelatihan yang diberikan. Tingkat pendidikan merupakan salah satu hal yang diduga ikut berpengaruh terhadap kemampuan masyarakat nelayan untuk dapat menyerap materi pelatihan yang disajikan.

Dalam melakukan pelatihan, seseorang pelatih (instruktur) dituntut terlebih dahulu mengetahui karakteristik peserta pelatihan, yakni: dari segi usia, tingkat pendidikan, dan pengetahuan dasar (kompetensi) yang dimilikinya serta karakteristikkarakteristik lainnya yang diperkirakan ikut berpengaruh terhadap pencapaian hasil pembelajaran yang dilakukan padanya. Berdasarkan karakeristik yang diketahuinya tersebut, pelatih (instruktur) menyeleksi dan menetapkan media yang hendak digunakan dalam pelaksanaan pelatihan tersebut.

Apabila melihat sifat materi keterampilan tentang pembuatan sanitasi rumah tinggal berwawasan lingkungan pada masyarakat nelayan cenderung bersifat teknis dan praktis. Adapun penggunaan media pelatihan tiga dimensi (media maket) pada masyarakat nelayan dapat melihat secara nyata, untuk mengetahui ukuran yang akan dibuat, dapat mengukur langsung media tiga dimensi (media maket) dengan skala yang ditentukan, karena media tiga dimensi (media maket) tersebut sama dengan bentuk aslinya dengan skala, hanya yang membedakan dalam bentuk ukuran kecil. Sedangkan pelatihan menggunakan media grafis (media gambar) daam pembuatan sanitasi rumah tingal berwawasan lingkungan pada masyarakat nelayan dapat membaca gambar kerja dan lebih cepat menangkap benda kongkritnya yang akan dibuat karena dapat membaca ukuran-ukuran serta keterangan/notasi pada media grafis (media gambar). 
Berdasarkan pemikiran ini, maka diduga bahwa keterampilan pembuatan sanitasi rumah tinggal berwawasan lingkungan secara keseluruhan masyarakat nelayan yang memiliki tingkat pendidikan tinggi mengikuti pelatihan menggunakan media grafis (media gambar) lebih tinggi dari pada menggunakan media tiga dimensi (media maket), karena masyarakat nelayan yang berpendidikan tinggi dapat memadukan antara pengetahuan gambar yang pernah didapatkan sebelumnya (kompetensi yang dimilikinya) dengan pengetahuan gambar yang didapatkan pada saat pelatihan. Mereka dapat membaca gambar baik ukuran-ukurannya maupun keterangan/notasi yang ada pada media grafis (media gambar). Selain itu, mereka terbuka terhadap ide dan pengalaman baru sehingga lebih cepat menangkap benda konkretnya yang akan dibuat.

7. Perbedaan Keterampilan Pembuatan Sanitasi Rumah Tinggal Berwawasan Lingkungan antara Masyarakat Nelayan yang Berpendidikan Rendah Mengikuti Pelatihan Menggunakan Media Tiga Dimensi (Media Maket) dengan yang Menggunakan Media Grafis (Media Gambar).

Keterampilan pembuatan sanitasi rumah tinggal berwawasan lingkungan adalah hasil belajar setelah masyarakat nelayan peserta pelatihan menerima bebagai pengalaman dalam peristiwa belajar tertentu pada setiap tahapan materi pelatihan yang diberikan. Untuk mengoptimalkan proses belajar dalam setiap peristiwa belajar dalam kegiatan pelatihan diperlukan suatu media pelatihan yang sesuai dengan karakteristik inovasi dari tiap individu masyarakat nelayan sebagai peserta pelatihan. Apabila diterapkan mampu menyerap materi pelatihan yang diberikan. Tingkat pendidikan merupakan salah satu hal yang diduga ikut berpengaruh terhadap kemampuan masyarakat nelayan untuk menyerap materi pelatihan yang disajikan.

Dalam melakukan pelatihan, seorang pelatih (instruktur) dituntut mengetahui karakteristik peserta pelatihan, yakni dari segi usia, tingkat pendidikan, dan pengetahuan dasar (kompetensi) yang dimilikinya serta karakteristik-karakteristik lainnya yang diperkirakan ikut berpengaruh terhadap pencapaian hasil pembelajaran. Berdasarkan karakeristik yang diketahuinya tersebut, pelatih (instruktur) menyeleksi dan menetapkan media yang hendak digunakan dalam pelaksanaan pelatihan tersebut.

Apabila melihat sifat materi keterampilan pembuatan sanitasi rumah tinggal berwawasan lingkungan, masyarakat nelayan yang berpendidikan rendah cenderung bersifat teknis dan praktis.Tingkat pendidikan masyarakat yang rendah menyebabkan keterbatasan keterampilan membaca gambar, sehingga mereka mengalami kesulitan membaca ukuran-ukuran gambar serta notasi gambar. Selain itu mereka kurang terbuka terhadap ide dan pengalaman baru. Mereka lebih percaya terhadap suatu inovasi apabila telah melihat keberhasilan orang lain di lapangan.

Pelatihan keteramplan menggunakan media tiga dimensi (media maket), masyarakat nelayan dapat melihat secara nyata (konkret) apa yang akan dibuat pada saat pelatihan. Dengan melihat media tiga dimensi (media maket) yang sama dengan bentuk aslinya yang akan dibuat, hanya yang membedakan skala kecil (miniatur). Jadi, keterampilan pembuatan sanitasi rumah tinggal berwawasan lingkungan akan mudah dicapai. Adapun dengan melalui pelatihan yang menggunakan media grafis (media gambar), masyarakat nelayan berpendidikan rendah pada saat pelatihan hanya dapat melihat secara abstrak apa yang akan dibuat.

Berdasarkan pemikiran ini, maka diduga bahwa keterampilan pembuatan sanitasi rumah tinggal berwawasan lingkungan secara keseluruhan dari masyarakat nelayan yang berpendidikan rendah bila mengikuti pelatihan menggunakan media tiga dimensi (media maket) akan lebih tinggi daripada menggunakan media grafis (media gambar).

\section{Hipotesis Penelitian}

Berdasarkan kerangka teori serta kerangka berpikir yang telah dikemukakan di atas, hipotesis penelitian dapat dirumuskan sebagai berikut:

1. Keterampilan pembuatan sanitasi rumah tinggal berwawasan lingkungan pada kelompok masyarakat nelayan yang mengikuti pelatihan menggunakan media tiga dimensi (media maket) lebih tinggi daripada kelompok masyarakat nelayan yang mengikuti pelatihan menggunakan media grafis (media gambar).

2. Terdapat pengaruh interaksi antara media pelatihan dan tingkat pendidikan terhadap keterampilan masyarakat nelayan tentang pembuatan sanitasi rumah tinggal berwawasan lingkungan.

3. Keterampilan pembuatan sanitasi rumah tinggal berwawasan lingkungan pada kelompok masyarakat nelayan yang berpendidikan tinggi yang mengikuti pelatihan menggunakan media grafis (media gambar) akan lebih tinggi dari pada peserta yang mengikuti pelatihan menggunakan media tiga dimensi (media maket).

4. Keterampilan pembuatan sanitasi rumah tinggal berwawasan lingkungan pada kelompok 
masyarakat nelayan yang berpendidikan rendah dan mengikuti pelatihan menggunakan media tiga dimensi (media maket) lebih tinggi daripada yang mengikuti pelatihan menggunakan media grafis (media gambar).

\section{METODOLOGI PENELITIAN}

Penelitian ini bertujuan: (1) Mengetahui perbedaan keterampilan pembuatan sanitasi rumah tinggal berwawasan lingkungan antara kelompok masyarakat nelayan yang mengikuti pelatihan menggunakan media tiga dimensi (media maket) dengan kelompok masyarakat nelayan yang mengikuti pelatihan menggunakan media grafis (media gambar); (2) Mengetahui interaksi antara media pelatihan dan tingkat pendidikan terhadap keterampilan masyarakat nelayan tentang pembuatan sanitasi rumah tinggal berwawasan lingkungan; (3) Mengetahui perbedaan keterampilan pembuatan sanitasi rumah tinggal berwawasan lingkungan antara kelompok masyarakat nelayan berpendidikan tinggi yang mengikuti pelatihan menggunakan media tiga dimensi (media maket) dengan kelompok masyarakat nelayan yang mengikuti pelatihan menggunakan media grafis (media gambar); (4) Mengetahui perbedaan keterampilan pembuatan sanitasi rumah tinggal berwawasan lingkungan antara kelompok masyarakat nelayan berpendidikan rendah yang mengikuti pelatihan menggunakan media tiga dimensi (media maket) dengan kelompok masyarakat nelayan yang mengikuti pelatihan menggunakan media grafis (media gambar).

Penelitian ini dilakukan pada halaman dan kolong rumah pangung masyarakat nelayan wilayah pantai di Desa Kupa dan Desa Bojo, Kecamatan Mallusetasi, Kabupaten Barru, Sulawesi Selatan. Pelatihan ini dilaksanakan mulai tanggal 20 November 2009 sampai dengan 20 Maret 2010. Seluruh rangkaian kegiatan penelitian ini dimulai dari persiapan, pelaksanaan pelatihan, sampai pada pelaksanan evaluasi keberhasilan pelatih. Pelaksanaan kegiatan pelatihan disesuaikan dengan kesepakatan antara masyarakat sasaran pelatihan dengan pelatih, yakni dimulai dari tahap penyajian materi pelatihan menggunakan media tiga dimensi (media maket) dan menggunakan media grafis (media gambar) sampai pada tahap pembuatan sanitasi rumah tinggal berwawasan lingkungan, yaitu: (1) pembuatan dan pemasangan tiang rangka jamban keluarga model panggung; (2) pembuatan dan pemasangan lantai, dinding, dan atap jamban keluarga model panggung; (3) pemasangan septictank dari buis beton dan instalasi pemipaannya; (4) pembuatan dan pemasangan drainase (comberan) untuk rumah panggung; (5) pembuatan dan pemasangan saringan penjernihan air bersih; (6) pembuatan dan pemasangan tempat sampah rumah tangga.

Pertemuan dilaksanakan dua kali seminggu yaitu: pelaksanaan satu kali dalam seminggu dilakukan di Desa Kupa dari dua kelompok yaitu: kelompok masyarakat nelayan yang berpendidikan tinggi diberikan pelatihan menggunakan media tiga dimensi (media maket), dan kelompok masyarakat nelayan yang berpendidikan rendah diberikan pelatihan menggunakan media grafis (media gambar), sedangkan pelaksanaan di Desa Bojo juga satu kali dalam seminggu dari dua kelompok yaitu: kelompok masyarakat nelayan yang berpendidikan tinggi diberikan pelatihan menggunakan media grafis (media gambar), dan kelompok masyarakat nelayan yang berpendidikan rendah diberikan pelatihan menggunakan media tiga

dimensi (media maket). Perlakuan diberikan selama enam kali pertemuan pelatihan di Desa Kupa dan enam kali juga petemuan pelatihan di Desa Bojo. Setiap kali pertemuan menggunakan waktu 2 x 30 menit pengenalan materi dan 15 x 30 menit setiap materi pelatihan.

Pengambilan sampel dalam penelitian ini dilakukan secara bertahap yang dimulai dengan random sampling untuk menentukan kecamatan dan desa dalam penelitian ini. Dilanjutkan dengan purposive sampling. Dari hasil random sampling terpilih Dusun Kupa, Dusun Labuange, dan Dusun Buaka, sedangkan Desa Bojo yang terdiri dari tiga dusun, yaitu: Dusun Bojo, Dusun Lojie, dan Dusun Labattoa.

Untuk mengetahui tingkat pendidikan tinggi dan rendah dilakukan dengan koesioner. Kom-posisi pengambilan sampel dapat dilihat pada Bagan 1 berikut ini:

\section{Gambar 1: Komposisi Populasi sampai Sampel}

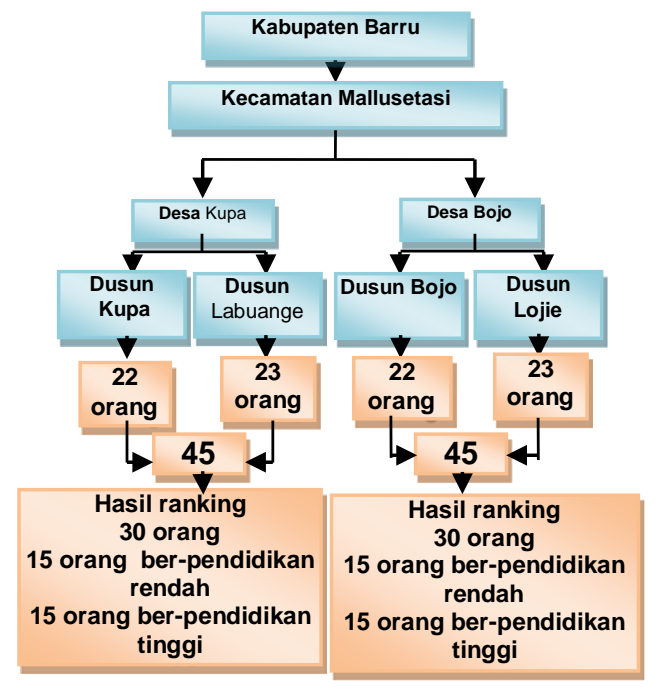


Langkah berikutnya adalah menentukan/menetapkan lokasi pelaksanan pelatihan. Untuk menetapkan/menentukan lokasi pelatihan pada kelompok masyarakat nelayan yang diberikan pelatihan membuat sanitasi rumah tinggal berwawasan lingkungan yang menggunakan media tiga dimensi (media maket) dan media grafis (media gambar), maka dilakukan lagi pemilihan lokasi secara random sampling terhadap kedua dusun yang terpilih tersebut. Dari hasil pemilihan lokasi tersebut ditetapkan Dusun Labuange Desa Kupa sebagai lokasi pelaksanaan pelatihan masyarakat nelayan yang berpendidikan tinggi menggunakan media tiga dimensi (media maket) dan masyarakat nelayan yang berpendidikan rendah menggunakan media grafis (media gambar) jumlah peserta masing-masing 15 orang, sedangkan di Dusun Lojie Desa Bojo sebagai lokasi pelaksanaan pelatihan masyarakat nelayan yang berpendidikan tinggi menggunakan media grafis (media gambar) dan masyarakat nelayan yang berpendidikan rendah menggunakan media tiga dimensi (media maket) jumlah peserta masing-masing 15 orang. Selanjutnya tempat dan materi kegiatan pelatihan dapat dilihat pada Bagan 2 berikut ini:

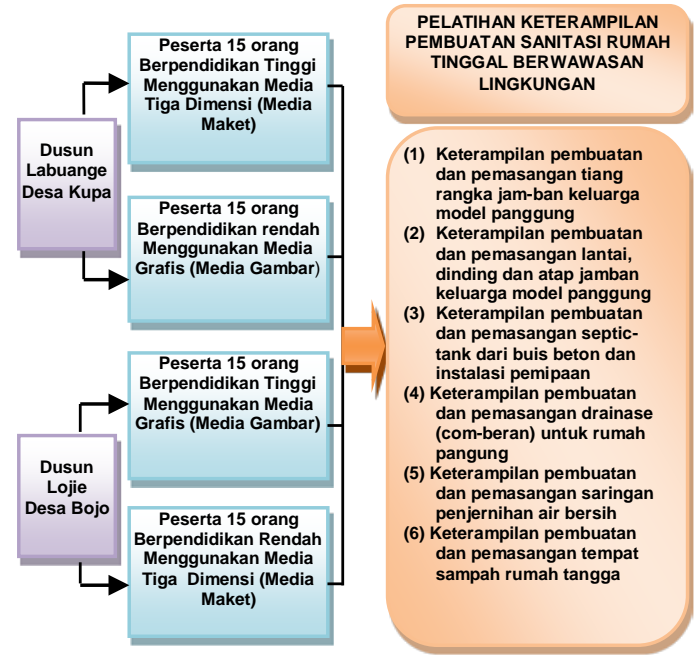

Teknik analisis data yang digunakan dalam penelitian ini adalah deskriptif dan analisis inferensial. Analisis deskriptif disajikan melalui tabel distribusi frekuensi, rata-rata, simpanan baku, dan histogram digunakan untuk mengetahui kebermaknaan interaksi tersebut. Sedangkan analisis inferensial digunakan untuk pengujian hipotesis penelitian yang diajukan. Namun sebelum dilakukan pengujian hipotesis terlebih dahulu dilakukan uji normalitas data dengan uji Lillifors dan uji homogenitas dengan menggunakan uji Bartlett (Gaspersz, 2003). Pengujian hipotesis dengan menggunakan analisis varian (Anava) dua jalur, dengan membandingkan angka $F_{\text {hitung }}$ dengan $F_{\text {tabel }}$ pada taraf signifikansi yang dipilih. Kemudian, jika dari hasil pengujian menunjukkan terdapat interaksi antra A dan B, maka pengujian dilanjutkan dengan Uji Tukey (Glass dan Hopkins, 1984), kemudian Untuk mengetahui keberartian interaksi tersebut. Data hasil penelitian dilakukan analisis varians (ANAVA) dua jalur. Desain rancangan disajikan pada Tabel 1 berikut ini:

Tabel 1. Rancangan Eksperimen Faktorial 2 x 2

\begin{tabular}{|c|c|c|c|}
\hline \multicolumn{2}{|c|}{$\begin{array}{l}\text { Variabel } \\
\text { Perlakuar } \\
\text { (A) }\end{array}$} & \multicolumn{2}{|c|}{ Media Pelatihan } \\
\hline $\begin{array}{c}\text { Variabel } \\
\text { Atribut } \\
\text { (B) }\end{array}$ & (A) & \begin{tabular}{|c} 
Menguna \\
kan \\
media \\
tiga \\
dimensi \\
(media \\
maket) \\
$\left(A_{1}\right)$
\end{tabular} & $\begin{array}{c}\text { Menggun } \\
\text { akan } \\
\text { media } \\
\text { grafis } \\
\text { (media } \\
\text { gambar) } \\
\left(A_{2}\right)\end{array}$ \\
\hline \multirow{2}{*}{$\begin{array}{c}\text { Tingkat } \\
\text { Pendidik } \\
\text { an }\end{array}$} & $\begin{array}{c}\text { Ting } \\
\text { gi } \\
\left(\mathrm{B}_{1}\right) \\
\end{array}$ & $A_{1} B_{1}$ & $A_{2} B_{1}$ \\
\hline & $\begin{array}{l}\text { Ren } \\
\text { dah } \\
\left(B_{2}\right)\end{array}$ & $A_{1} B_{2}$ & $A_{2} B_{2}$ \\
\hline
\end{tabular}

Keterangan:

Variabel Terikat $(\mathrm{Y})=$ Keterampilan pembuatan sanitasi rumah tinggal berwawasan lingkungan

Unit Analisis = Masyarakat nelayan

Variabel Bebas:

- Perlakuan (A) = Media pelatihan $\mathrm{A}_{1}=$ Menggunakan media tiga dimensi (media maket) $\mathrm{A}_{2}=$ Menggunakan media grafis (media

gambar)

- Atribut (B) = Tingkat Pendidikan

$\mathrm{B}_{1}=$ Pendidikan Tinggi

$\mathrm{B}_{2}=$ Pendidikan Rendah

Hipotesis statistik yang akan diuji sebagai berikut:

1. Hipotesis 1: $\mathrm{H}_{0}: \mu \mathrm{A}_{1} \leq \mu \mathrm{A}_{2}$ $\mathrm{H}_{1}: \mu \mathrm{A}_{1}>\mu \mathrm{A}_{2}$

2. Hipotesis 2: $\mathrm{H}_{0} \quad$ : int. $\mathrm{AxB}=0$ $\mathrm{H}_{1} \quad$ : int. $\mathrm{AxB} \neq 0$ 
3. Hipotesis 3: $\quad \mathrm{H}_{0}: \mu \mathrm{A}_{1} \mathrm{~B}_{1} \geq \mu \mathrm{A}_{2} \mathrm{~B}_{1}$

$H_{1}: \mu A_{1} B_{1}<\mu A_{2} B_{1}$

4. Hipotesis 4: $\mathrm{H}_{0}: \mu \mathrm{A}_{1} \mathrm{~B}_{2} \leq \mu \mathrm{A}_{2} \mathrm{~B}_{2}$

$\mathrm{H}_{1}: \mu \mathrm{A}_{1} \mathrm{~B}_{2}>\mu \mathrm{A}_{2} \mathrm{~B}_{2}$

\section{HASIL PENELITIAN}

\section{Deskripsi Data Hasil Penelitian}

Tabel 2. Rangkuman Hasil Perhitungan Data Keterampilan Pembuatan Sanitasi Rumah Tinggal Berwawasan Lingkungan

\begin{tabular}{|c|c|c|c|}
\hline $\begin{array}{l}\text { Media } \\
\text { Pelatihan } \\
\text { Tingkat } \\
\text { Pendidikan }\end{array}$ & $\begin{array}{c}\text { Media } \\
\text { Tiga } \\
\text { Dimensi } \\
\text { (Media } \\
\text { Maket) } \\
\text { (A1) }\end{array}$ & $\begin{array}{c}\text { Media } \\
\text { Grafis } \\
\text { (Media } \\
\text { Gambar) } \\
\text { (A2) }\end{array}$ & Total \\
\hline $\begin{array}{l}\text { Pendidikan } \\
\text { Tinggi } \\
\text { (B1) }\end{array}$ & $\begin{array}{ll}n_{y 1} & = \\
15 & \\
\sum Y_{1} & = \\
2.698 & \\
\sum Y_{1}^{2}= & = \\
487,210 & = \\
Y_{1} & = \\
179,867 & = \\
S_{y 1}= \\
11,74 \\
S_{y 1}^{2}= \\
137,838\end{array}$ & $\begin{array}{l}n_{y 2}= \\
15 \\
\sum Y_{2}= \\
2.992 \\
\sum Y_{2}^{2}= \\
599,612 \\
\bar{Y}_{2}= \\
199,467 \\
S_{y 2}= \\
14,162 \\
S_{y 2}^{2}= \\
200,552\end{array}$ & $\begin{array}{l}n_{b 1}= \\
\mathbf{3 0} \\
\sum_{b 1}= \\
\mathbf{5 . 6 9 0} \\
\sum_{b}^{2}= \\
\mathbf{1 . 0 8 6 , 8 2 2} \\
\overline{Y_{b 1}}= \\
\mathbf{1 8 9 , 6 6 7}= \\
S_{b 1}= \\
\mathbf{1 6 , 2 0 8}= \\
S_{b 1}^{2}= \\
\mathbf{2 6 2 , 7 1 3}\end{array}$ \\
\hline $\begin{array}{l}\text { Pendidikan } \\
\text { Rendah } \\
\text { (B2) }\end{array}$ & $\begin{array}{ll}n_{y 3} & = \\
15 & \\
\sum Y_{3}= & = \\
2.456 & \\
\sum Y_{3}^{2}= & \\
405,13 & \\
\bar{Y}_{3} & = \\
163,733 & = \\
S_{y 3}= \\
3,24 \\
S_{y 3}^{2}= \\
214,495\end{array}$ & $\begin{array}{l}n_{y 4}= \\
15 \\
\sum Y_{4}= \\
1.738 \\
\sum_{4}= \\
204,724 \\
\bar{Y}_{4}= \\
115,867 \\
= \\
S_{y 4}= \\
15,464 \\
S_{y 4}^{2}= \\
239,124\end{array}$ & $\begin{array}{c}n_{b 2}= \\
30 \\
\sum_{Y_{b 2}}= \\
4.194 \\
\sum_{Y_{b 2}^{2}}= \\
609,856 \\
\overline{Y_{b 2}}= \\
\mathbf{1 3 9 , 8}= \\
S_{b 2}= \\
28,488 \\
S_{b 2}^{2}= \\
811,545\end{array}$ \\
\hline & $\begin{array}{l}n_{k 1}= \\
30 \\
\sum Y_{k 1}= \\
5.154\end{array}$ & $\begin{array}{l}n_{k 2}= \\
30 \\
\sum_{k 2}= \\
4.730\end{array}$ & $\begin{array}{l}n_{t}= \\
60 \\
\sum_{Y_{t}}= \\
9.884\end{array}$ \\
\hline
\end{tabular}

\begin{tabular}{|c|c|c|c|}
\hline Total & \begin{tabular}{|l}
$\sum Y_{k 1}^{2}=$ \\
$\mathbf{8 9 2 , 3 4 2}$ \\
$\bar{Y}_{k 1}=$ \\
171,8 \\
$S_{k 1}=$ \\
15,408 \\
$S_{k 1}^{2}$ \\
$=$ \\
$\mathbf{2 3 7 , 4 0 7}$
\end{tabular} & $\mid \begin{array}{l}\sum Y_{k 2}^{2}= \\
804,336 \\
\overline{Y_{k 2}}= \\
157,667 \\
S_{k 2}= \\
44,942 \\
S_{k 2}^{2}= \\
2019,75\end{array}$ & \begin{tabular}{|l}
$Y_{t}^{2}=$ \\
$1.696,678$ \\
$\bar{Y}_{t}=$ \\
164,733 \\
$S_{t}=$ \\
34,062 \\
$S_{t}^{2}=$ \\
1160,23
\end{tabular} \\
\hline
\end{tabular}

\section{Hasil Penelitian dan}

\section{Pembahasan}

Pengujian hipotesis pada penelitian ini menggunakan Analisis Varians (Anava) dua jalur pada taraf signifikansi $5 \%(\alpha=0,05)$. Adapun kriteria pengujian adalah (1) jika

antar kolom nilai $\mathrm{F}_{\text {hitung }}$ lebih besar dari pada $\mathrm{F}_{\text {tabel }}$ $\left(F_{\text {hitung }}>F_{\text {tabel }}\right)$, maka dapat dinyatakan terdapat perbedaan yang signifikan, (2) jika untuk interaksi nilai $F_{\text {hitung }}$ lebih besar dari pada $F_{\text {tabel }}\left(F_{\text {hitung }}>\right.$ $\left.\mathrm{F}_{\text {tabel}}\right)$, dinyatakan terdapat interaksi yang signifikan, maka dianjutkan uji Tukey untuk mengetahui kebermaknaan atau efek interaksi tersebut. Untuk hipotesis (3) dan (4) menggunakan uji Tukey. Jika Qhitung $\geq$ Qtabel dinyatakan terdapat perbedaan antara kelompok yang dibandingkan.

Hasil analisis data dengan Analisis Varians (ANAVA) dua jalur data keterampilan dalam pembuatan sanitasi rumah tinggal berwawasan lingkungan dapat dilihat pada Tabel 3 berikut ini:

Tabel 3.

Rangkuman Hasil Perhitungan

ANAVA Dua Jalur Data Keterampilan Pembuatan Sanitasi Rumah Tinggal Berwawasan Lingkungan

\begin{tabular}{||c|c|c|c|c|c||}
\hline $\begin{array}{c}\text { Sumber } \\
\text { Variansi }\end{array}$ & $\begin{array}{c}\mathrm{d} \\
\mathrm{k}\end{array}$ & $\begin{array}{c}\text { Jumlah } \\
\text { Kuadrat } \\
\text { (JK) }\end{array}$ & $\begin{array}{c}\text { Rerata } \\
\text { Kuadrat } \\
\text { (RJK) }\end{array}$ & F $_{\text {Hitung }}$ & $\begin{array}{c}\text { F } \\
(0,05 \\
\text { Tabel }\end{array}$ \\
\hline \hline $\begin{array}{c}\text { Media } \\
\text { Pelatihan } \\
\text { (A) }\end{array}$ & 1 & 2996.267 & 2996.267 & 15.132 & $\begin{array}{c}4.01 \\
3\end{array}$ \\
\hline $\begin{array}{c}\text { Tingkat } \\
\text { Pendidik } \\
\text { an (B) }\end{array}$ & 1 & $\begin{array}{c}37300.26 \\
7\end{array}$ & $\begin{array}{c}37300.26 \\
7\end{array}$ & $\begin{array}{c}188.38 \\
3\end{array}$ & $\begin{array}{c}4.01 \\
3\end{array}$ \\
\hline $\begin{array}{c}\text { Interaksi } \\
\text { antar A X } \\
\text { B }\end{array}$ & 1 & $\begin{array}{c}17069.06 \\
7\end{array}$ & $\begin{array}{c}17069.06 \\
7\end{array}$ & 86.206 & $\begin{array}{c}4.01 \\
3\end{array}$ \\
\hline $\begin{array}{c}\text { Dalam } \\
\text { Kelompo } \\
\text { K }\end{array}$ & $\begin{array}{c}5 \\
6\end{array}$ & $\begin{array}{c}11088.13 \\
3\end{array}$ & 198.002 & & \\
\hline Total & 5 & $\begin{array}{c}125819.3 \\
9\end{array}$ & 33 & & \\
\hline \hline
\end{tabular}

Keterangan: 


$$
\begin{array}{ll}
\mathrm{dk} & =\text { derajat kebebasan } \\
\alpha & =\text { taraf signifikansi }
\end{array}
$$

Jadi, disimpulkan bahwa terdapat perbedaan antara media pelatihan menggunakan media tiga dimensi (media maket) $\mathrm{A}_{1}$ dengan menggunakan media grafis (media gambar) $A_{2}$, dan interaksi atau terdapat pengaruh media pelatihan (A) dan tingkat pendidikan (B) terhadap keterampilan masyarakat nelayan tentang pembuatan sanitasi rumah tinggal berwawasan lingkungan. Dapat dilihat Grafik Interaksi pada Gambar 1 berikut ini:

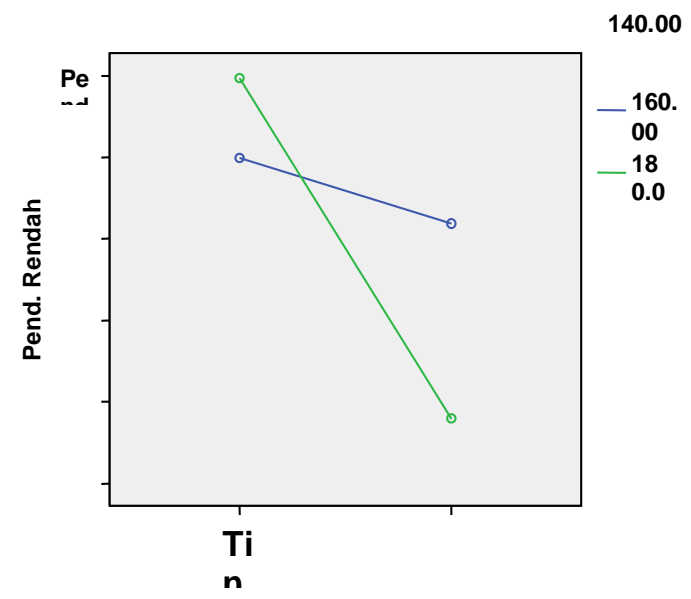

Gambar 1. Grafik Interaksi antara Media Pelatihan dengan Tingkat Pendidikan

Dari hasil perhitungan Analisis Varians (ANAVA) dua jalur seperti tertera dalam Tabel 3 dan Gambar 1 di atas, diketahui bahwa terdapat interaksi antara media pelatihan dengan tingkat pendidikan ( $\mathrm{A} \mathrm{x}$ B), maka dilanjutkan dengan uji Tukey.

Tabel 4. Rangkuman Hasil Uji Tukey

\begin{tabular}{||c|c|c|c|c|c|c||}
\hline $\begin{array}{c}\text { Kelompok } \\
\text { yang } \\
\text { Dibandingkan }\end{array}$ & $\mathbf{N}$ & $\mathbf{K}$ & $\mathbf{d k}$ & $\mathbf{Q}_{\text {hitung }}$ & $\mathbf{Q}_{\text {tabel }}$ & Kesimpulan \\
\hline \hline $\begin{array}{c}\mathbf{A}_{1} \mathbf{B}_{1} \text { dan } \\
\mathbf{A}_{2} B_{1}\end{array}$ & 60 & 4 & $(3 ; 56)$ & 5.394 & 5.690 & $\begin{array}{c}\text { Tidak } \\
\text { Signifikan }\end{array}$ \\
\hline $\begin{array}{c}\mathbf{A}_{1} \mathbf{B}_{2} \text { dan } \\
\mathbf{A}_{2} B_{2}\end{array}$ & 60 & 4 & $(3 ; 56)$ & 13.1755 .690 & Signifikan \\
\hline
\end{tabular}

1. Perbedaan nilai rerata absolut kelompok $A_{1} B_{1}$ dan $\mathbf{A}_{2} B_{1}$

Berdasarkan tabel diperoleh Qhitung $=Q_{\text {hitung }}=$ $5.394<\mathrm{Q}_{\text {tabel }}=5.690$ yang berarti secara statistik signifikan untuk menerima hipotesis $\mathrm{H}_{0}$ atau menolak hipotesis $\mathrm{H}_{1}$ yaitu tidak terdapat perbedaan antara kelompok $\mathrm{A}_{1} \mathrm{~B}_{1}$ dan $\mathrm{A}_{2} \mathrm{~B}_{1}$. Hasil analisis data menunjukkan bahwa kelompok masyarakat nelayan berpendidikan tinggi mengikuti pelatihan menggunakan media tiga dimensi (media maket) grafis (media gambar) dengan kelompok masyarakat nelayan berpendidikan tinggi mengikuti pelatihan menggunakan media grafis (media gambar) tidak ada perbedaan.

\section{Perbedaan nilai rerata absolut kelompok $A_{1} B_{2}$} dan $\mathbf{A}_{2} \mathbf{B}_{2}$

Berdasarkan tabel diperoleh Qhitung $=13.175 \geq$ $\mathrm{Q}_{\text {tabel }}=5.690$ yang berarti secara statistik signifikan untuk menolak hipotesis $\mathrm{H}_{0}$ atau menerima hipotesis $\mathrm{H}_{1}$ yaitu terdapat perbedaan antara kelompok $A_{1} B_{2}$ dan $A_{2} B_{2}$. Dari rerata menunjukkan bahwa kelompok masyarakat nelayan berpendidikan rendah mengikuti pelatihan menggunakan media tiga dimensi (media maket) lebih tinggi dibandingkan dengan kelompok pelatihan yang menggunakan media grafis (media gambar).

Berdasarkan hasil perhitung-an Anava (ANAVA) dua jalur (Tabel 3) dan Uji Tukey (Tabel 4), maka dapat dijelaskan sebagai berikut:

1. Pebedaan keterampilan pembuatan sanitasi rumah tinggal berwawasan lingkungan antara kelompok masyarakat nelayan yang mengikuti pelatihan menggunakan media tiga dimensi (media maket) $A_{1}$ dengan menggunakan media grafis (media gambar) $\mathbf{A}_{2}$.

Berdasarkan analisis varians (ANAVA) pada bagian pelatihan mengunakan media tiga dimensi (media maket) $\mathrm{A}_{1}$ dengan media grafis (media gambar) $A_{2}$ diperoleh nilai $F_{\text {hitung }}=15,132>F_{\text {tabel }}=$ 4,013 atau menggunakan nilai peluang sig. $=0,000$ yang lebih dari taraf signifikan $(\alpha)=0,05$ yang berarti secara statistik signifikan untuk menolak hipotesis $\mathrm{H}_{0}$ atau menerima hipotesis $\mathrm{H}_{1}$, yaitu terdapat perbedaan antara kelompok masyarakat nelayan yang mengikuti pelatihan menggunakan media tiga dimensi (media maket) $A_{1}$ dan kelompok masyarakat nelayan yang mengikuti pelatihan menggunakan media grafis (media gambar) $A_{2}$. Dari rerata menunjukkan bahwa kelompok masyarakat nelayan yang mengikuti pelatihan menggunakan media tiga dimensi (media maket) $A_{1}$ lebih tinggi dibandingkan kelompok masyarakat nelayan mengikuti pelatihan menggunakan media grafis (media gambar) $\mathrm{A}_{2}$. Namun demikian penggunaan media grafis (media gambar) $A_{2}$ tetap juga memberikan keterampilan bagi kelompok masyarakat nelayan dalam pembuatan sanitasi rumah tinggal berwawasan lingkungan.

Keterampilan kelompok masyarakat nelayan yang mengikuti pelatihan menggunakan media tiga dimensi (media maket) dalam pembuatan sanitasi rumah tinggal berwawasan lingkungan lebih tinggi, dimungkinkan karena melihat langsung, mengukur sendiri pada media tiga dimensi (media maket) mulai 
dari ukuran, bahan yang digunakan, serta bentuk sanitasi rumah tinggal berwawasan lingkungan yaitu: (1) tiang rangka jamban keluarga model panggung; (2) lantai, dinding dan atap jamban keluarga model panggung; (3) septictank dari buis beton dan instalasi pemipaannya; (4) drainase (comberan) untuk rumah panging; (5) saringan penjernihan air bersih; (6) tempat sampah rumah tangga. Sedangkan keterampilan kelompok masyarakat nelayan yang mengikuti pelatihan menggunakan media grafis (media gambar) hanya melihat gambar tanpa melihat miniaturnya tetapi ukuran dan notasi gambar sangat jelas.

2. Pengaruh interaksi antara media pelatihan (A) dan tingkat pendidikan (B) terhadap keterampilan masyarakat nelayan tentang pembuatan sanitasi rumah tinggal berwawasan lingkungan.

Berdasarkan hasil pengujian analisis varians (Anava) pada bagian interaksi antara media pelatihan A dengan tingkat pendidikan $\mathrm{B}$ diperoleh nilai $\mathrm{F}_{\text {hitung }}=$ 86,206 $>\mathrm{F}_{\text {tabel }}=4,013$ atau menggunakan nilai peluang sig. $=0,000$ yang lebih dari taraf signifikan $\alpha$ $=0,05$ yang berarti secara statistik signifikan untuk menolak hipotesis $\mathrm{H}_{0}$ atau menerima hipotesis $\mathrm{H}_{1}$. Jadi, disimpulkan bahwa media pelatihan ternyata memberikan interaksi atau pengaruh terhadap tingkat pendidikan bagi kelompok masyarakat nelayan dalam keterampilan pembuatan sanitasi rumah tinggal berwawasan lingkungan. Kelompok masyarakat nelayan yang berpendidikan tinggi memiliki keterampilan yang lebih tinggi dibandingkan dengan kelompok masyarakat nelayan yang berpendidikan rendah.

3. Perbedaan keterampilan pembuatan sanitasi rumah tinggal berwawasan lingkungan antara kelompok masyarakat nelayan yang berpendidikan tinggi yang mengikuti pelatihan menggunakan media tiga dimensi (media maket) $A_{1} B_{1}$ dengan menggunakan media grafis (media gambar) $A_{2} B_{1}$.

Berdasarkan hasil pengujian lanjut dengan menggunakan uji tukey diperoleh nilai $\mathrm{Q}_{\text {hitung }}=5.394$ $<Q_{\text {tabel }}=5.690$ yang berarti secara statistik signifikan untuk menerima hipotesis $\mathrm{H}_{0}$ atau menolak hipotesis $\mathrm{H}_{1}$ yaitu tidak terdapat perbedaan antara kelompok masyarakat nelayan yang berpendidikan tinggi mengikuti pelatihan menggunakan media tiga dimensi (media maket) $\mathrm{A}_{1} \mathrm{~B}_{1}$ dan kelompok masyarakat nelayan yang berpendidikan tinggi mengikuti pelatihan menggunakan media grafis (media gambar) $\mathrm{A}_{2} \mathrm{~B}_{1}$. Dari rerata menunjukkan bahwa kelompok masyarakat nelayan yang berpendidikan tinggi mengikuti pelatihan menggunakan tiga dimensi (media maket) $A_{1} B_{1}$ tidak ada perbedaan atau sama saja dengan kelompok masyarakat nelayan yang berpendidikan tinggi mengikuti pelatihan menggunakan media grafis (media gambar) $\mathrm{A}_{2} \mathrm{~B}_{1}$.
4. Perbedaan keterampilan pembuatan sanitasi rumah tinggal berwawasan lingkungan antara kelompok masyarakat nelayan yang berpendidikan rendah dan mengikuti pelatihan menggunakan media tiga dimensi (media maket) $A_{1} B_{2}$ dengan menggunakan media grafis (media gambar) $A_{2} B_{2}$.

Berdasarkan hasil pengujian lanjut dengan menggunakan uji tukey diperoleh nilai Qhitung $=13.175$ $\geq \mathrm{Q}_{\text {tabel }}=5.690$ yang berarti secara statistik signifikan untuk menolak hipotesis $\mathrm{H}_{0}$ atau menerima hipotesis $\mathrm{H}_{1}$, yaitu terdapat perbedaan antara kelompok masyarakat nelayan yang berpendidikan rendah mengikuti pelatihan menggunakan media tiga dimensi (media maket) $\mathrm{A}_{1} \mathrm{~B}_{2}$ dan kelompok masyarakat nelayan yang berpendidikan rendah mengikuti pelatihan menggunakan media grafis (media gambar) $\mathrm{A}_{2} \mathrm{~B}_{2}$. Dari rerata menunjukkan bahwa kelompok masyarakat nelayan yang berpendidikan rendah mengikuti pelatihan menggunakan media tiga dimensi (media maket) $\mathrm{A}_{1} \mathrm{~B}_{2}$ lebih tinggi dibandingkan kelompok masyarakat nelayan yang berpendidikan rendah mengikuti pelatihan mengunakan media grafis (media gambar) $\mathrm{A}_{2} \mathrm{~B}_{2}$. Dengan demikian dapat dipahami bahwa walaupun kedua kelompok memilki pendidikan rendah, namun keterampilan bisa berbeda dan yang lebih tinggi adalah kelompok masyarakat nelayan yang diberikan pelatihan menggunakan media tiga dimensi (media maket) $\mathrm{A}_{1} \mathrm{~B}_{2}$.

\section{KESIMPULAN}

Hasil penemuan dalam penelitian ini dapat disimpulkan sebagai berikut:

1. Terdapat perbedaan keterampilan dalam pembuatan sanitasi rumah tinggal berwawasan lingkungan antara kelompok masyarakat nelayan yang mengikuti pelatihan menggunakan media tiga dimensi (media maket) dengan yang mengikuti pelatihan menggunakan media grafis (media gambar). Yang lebih tinggi adalah kelompok masyarakat nelayan yang mengikuti pelatihan menggunakan media tiga dimensi (media maket).

2. Terdapat pengaruh interaksi antara media pelatihan dengan tingkat pendidikan dalam pembuatan sanitasi rumah tinggal berwawasan lingkungan antara kelompok masyarakat nelayan yang mengikuti pelatihan menggunakan media tiga dimensi (media maket) dengan yang mengikuti pelatihan menggunakan media grafis (media gambar). Hal ini terjadi baik pada kelompok masyarakat nelayan yang berpendidikan tinggi maupun pada kelompok masyarakat nelayan yang berpendidikan rendah.

3. Tidak terdapat perbedaan keterampilan dalam pembuatan sanitasi rumah tinggal berwawasan 
lingkungan. Kelompok masyarakat nelayan yang berpendidikan tinggi yang mengikuti pelatihan dengan menggunakan media tiga dimensi (media maket) tidak terdapat perbedaan atau sama saja keterampilannya dengan masyarakat nelayan berpendidikan tinggi mengikuti pelatihan menggunakan media grafis (media gambar).

4. Terdapat perbedaan keterampilan dalam pembuatan sanitasi rumah tinggal berwawasan lingkungan. Kelompok masyarakat nelayan yang berpendidikan rendah yang mengikuti pelatihan menggunakan media tiga dimensi (media maket) lebih tinggi keterampilannya dibandingkan masyarakat nelayan yang berpendidikan tinggi mengikuti pelatihan menggunakan media grafis (media gambar).

Berdasarkan temuan-temuan tersebut di atas, dapat disimpulkan bahwa pembentukan keterampilan pembuatan sanitasi rumah tinggal berwawasan lingkungan dipengaruhi oleh media pelatihan yang digunakan pelatih (instruktur) dan tingkat pendidikan masyarakat nelayan peserta pelatihan.

\section{Implikasi Hasil Penelitian}

Implikasi hasil penelitian sebagai berikut:

1. Penemuan pertama peneltian ini mengungkapkan bahwa secara keseluruhan pelatihan mengunakan media tiga dimensi (media maket) lebih tinggi dibandingkan dengan pelatihan menggunakan media grafis (media gambar) terhadap pembentukan keterampilan pembuatan sanitasi rumah tinggal berwawasan lingkungan. Artinya pelatihan menggunakan media tiga dimensi (media maket) memberikan pengaruh yang cukup tinggi terhadap peningkatan keterampilan masyarakat nelayan dalam pembuatan sanitasi rumah tinggal berwawasan lingkungan. Betapa pentingnya penggunaan media tiga dimensi (media maket) itu diterapkan bagi masyarakat secara umum dan masyarakat nelayan khususnya yang memiliki tingkat akademisi relatif kurang. Oleh karena itu diharapkan kiranya pelatihan menggunakan media tiga dimensi (media maket) ini perlu lebih dikembangkan lagi dan diterapkan secara berkesinambungan. Diharapkan bagi para tenaga pelatih/ instruktur lebih banyak menggunakan media tiga dimensi (media maket) dalam melakukan suatu kegiatan pelatihan khususnya yang berkaitan dengan pelatihan-pelatihan keterampilan bagi masyarakat nelayan yang berpendidikan relatif terbatas.

2. Penemuan kedua dalam penelitian ini mengungkapkan bahwa terdapat pengaruh interaksi antara media pelatihan yang digunakan dengan tingkat pendidikan masyarakat nelayan terhadap keterampilan pembuatan sanitasi rumah tinggal berwawasan lingkungan. Hasil penemuan ini juga memperkuat penemuan-penemuan lainnya dalam penelitian ini, bahwa pelatihan keterampilan menggunakan media tiga dimensi (media maket) lebih tinggi dibandingkan dengan menggunakan media gambar (media grafis).

3. Penemuan ketiga dalam penelitian ini mengungkapkan bahwa keterampilan pembuatan sanitasi rumah tinggal berwawasan lingkungan pada kelompok masyarakat nelayan yang berpendidikan tinggi mengikuti pelatihan menggunakan media tiga dimensi (media maket) dengan kelompok masyarakat nelayan yang berpendidikan tinggi mengkuti pelatihan menggunakan media grafis (media gambar) tidak ada perbedaan. Hal ini merupakan suatu petunjuk bahwa masyarakat nelayan yang berpendidikan tinggi mengikuti pelatihan menggunakan media tiga dimensi (media maket) dan menggunakan media grafis (media gambar) merupakan pilihan yang tepat untuk digunakan dalam pelatihan keterampilan sehingga dapat memberikan hasil optimal.

4. Penemuan keempat dalam penelitian ini mengungkapkan bahwa keterampilan pembuatan sanitasi rumah tinggal berwawasan lingkungan pada kelompok masyarakat nelayan yang berpendidikan rendah mengikuti pelatihan menggunakan media tiga dimensi (media maket) lebih tinggi dibandingkan dengan kelompok masyarakat nelayan yang berpendidikan rendah mengikuti pelatihan menggunakan media grafis (media gambar). Hal ini merupakan suatu petunjuk bahwa masyarakat nelayan yang berpendidikan rendah bila mengikuti pelatihan menggunakan media tiga dimensi (media maket) merupakan pilihan yang tepat digunakan dalam pelatihan keterampilan sehingga memberikan hasil optimal.

\section{Saran}

Berdasarkan kesimpulan dan implikasi yang telah diuraikan di atas, dapat dikemukakan beberapa saran sebagai berikut:

1. Bagi Pemerintah Propinsi Sulawesi Selatan, Pemerintah Daerah Kabupaten Barru dalam upaya mewujudkan sanitasi rumah tinggal berwawasan lingkungan pada masyarakat nelayan, perlu diberikan keterampilan pembuatan sanitasi rumah tinggal menggunakan media pelatihan yaitu media tiga dimensi (media maket) dan media grafis (media gambar) dalam pelatihan pembuatan jamban keluarga model panggung, drainase (comberan) untuk rumah panggung, perjernihan air bersih, dan tempat sampah rumah tangga sehingga 
masyarakat nelayan dapat hidup sehat dan sejahtera.

2. Bagi peneliti Pendidikan Lingkungan pengembangan penelitan juga disarankan menggunakan media pelatihan yang lain dan dapat melanjutkan penelitian ini degan variabel yang lain agar dapat meningkatkan keterampilan pembuatan sanitasi rumah tinggal berwawasan lingkungan sehingga masyarakat dapat hidup sehat dan sejahtera.

3. Bagi kelompok masyarakat nelayan supaya berperilaku, dan bertindak sesuai pada tempatnya agar dapat hidup berwawasan lingkungan sehingga terwujud lingkungan yang lebih baik menuju hidup sehat dan sejahtera.

\section{DAFTAR PUSTAKA}

Antoniades, Anthony C. Architecture and Allied Design an Environmental Design Perspective. Dubuque, Lowa USA: Kendall/Hunt Publishing Coy, 1980

Amsyari, Fuad. Membangun Lingkungan Sehat. Surabaya: Airlangga University Press, 1996

Ary, Donald, Luchy Cheser Jacobs, and Asghar Razavish. Introduction to Research in Education. New York: CBS College Publishing, 1985.

Arsyad, Azhar. Media Pembelajaran. Jakarta: Raja Grafindo Persada, 2009.

Aswar, Azrul. Pengantar Ilmu Kesehatan Lingkungan. Jakarta: Mutiara Sumber Widya, 1996.

Babitt, Harold E. and E. Robert Bannana. Plumbing. New York: John Wiley \& Sons, Inc,1969.

Baron, Robert A and Donn Byrne. Social Psychology: Understanding Human Interaction. Boston: Allyn and Bacon, 1991.

Bell, Paul A. et al. Environmental Psychology. USA: New York, 1996.

BPS. Kabupaten Barru dalam Angka. Barru: BPS, 2009.

Bruner, Jerome S. Toward a Theory of Instruction. Cambridge: Harvard University, 1966.

Cointren, Sandra J. Environmental Management of Orban Solid Waste in Development: A Project Gide. Washington DC: The Worlk Bank, 1982.

Chandra, Budiman. Pengantar Kesehatan Lingkungan. Jakarta: Buku Kedokteran EGC, 2007.
Chiras, Daniel D. Environmental Science, A Framework for Decision Making. California: The Benjamin/Cummings Publishing Company, Inc, 1990.

Davis, Bob, Ros Bull, Jan Roscoe. Physical Education, and the Study of Sport. New York: Mosby Publishing Company, 1985.

Ehles, Victor M. C.E., at el. Minicipal and Reir al Sanitation. New York: Mc Graw Hill Book Company, inc., 1988

Fairweather, Lesle, AJ Metric. Handbook. London: The Architectural Press, $\mathrm{tt}$ )

Franceys, R, J. Pickford \& R. Reed. A Guide To The Development of on State Sanitation. Geneva: WHO, 1992.

Frick, Heinz, Tri Hesti Mulyani. Arsitektur Ekologis. Seri Eko-Arsitektur 2. Semarang: Karnisius, 2006.

Galass, Gene V dan Kenneth D. Hopkins. Statistical Methods in Education and Psychology. New Jersey: Englewood Eliffs, Printice-Hall, Inc., 1984.

Gaspersz, Vincent. Metode Perancangan Percobaan Ilmu-Ilmu Pertanian, Ilmu-ilmu Teknik, dan Biologi. Bandung, Armico, 2003.

Gardner, Gerald T. and Paul C. Stern. Environmental Problems and Human Behaviour. Boston: Allyn and Bacon, 1996.

Gay L.R., Peter Airasian. Educational Research: Compotencies for Analysis and Aplication. New Jersey: Prentice Hall Inc. Englewood Clitts, 1996.

Good, Thomas L, Jere E. Brophy. Educational Psychology: A Realictics Approach, Second Edition. New York: Longman, 1990

Hakim, Rustam, Hardi Utomo. Komponen Perancangan Arsitektur Lansekap, Prinsip Unsur dan Aplikasi Disain. Jakarta: Bumi Aksara, 2008.

Hakim, Rustam dan Eka Sediadi R. Komunikasi Grafis, Arsitektur dan Lansekap. Jakarta: Bumi Aksara, 2006.

Hopkins, Kenneth D, Julian C Stanley, B.R. Hopkins. Educational and Psychological Measurement and Evaluation. New Jersey: Prentice Hall Inc. 1981.

Inkeles, Alex, and David H. Smith. Becoming Modern: Individual Change in Six Developing Countries. Canbridge, 
Massachusetts: Harvard University Press, 1992.

Johannes, F Linn. Cities in the Developng World: Policies for Their Equitable \& Efficient Growth. USA: Oxfold, 1983.

Joyce, Bruce, Marsha Weil and Emily Calhoun. Models of Teaching. New Jersey: Pretice Hall, Inc, Englewood Cliffs, 2009.

Kemp, Jerrold E. and Don C. Smellie. Planning, Producing, and Using Instructional Media (Sixth Edition). New York: Harper \& Row, Publishers, 1989.

Kennet, N. Wexiey and Latham Gary. Development and Training Human Resouces in Organization. Harper Colins Publisher, 1971

Khol, Herbert, Basic Skill. Toronto: Bantam Book, 1984.

Koentjaraningrat. Kebudayaan, Mentalitas, Pembangunan. Jakarta: Gramedia, 1994.

Kusnoputranto, Haryoto. Air Limbah dan Ekskreta Manusia, Aspek Kesehatan Masyarakat dan Pengelolaannya. Jakarta: Direktorat Jenderal Pendidikan Tinggi Departemen Pendidikan dan Kebudayaan, 1997.

Lang, Jon. Creating Architectural Theory, The Role of the Behavioral Sciences in Environmental Design. New York: Van Nostrand Reinhold Company, 1987.

Laurens, Joyse Marcella. Arsitektur dan Perilaku Manusia. Surabaya: Grasindo, 2005.

Leighbody, Generald B, dan Kidd Donald M. Methods of Teaching Shop and Technical Subjects. New York: Delmar Publisher, 1968.

Lohr, Linda L. Creating Graphics for Learning and Performance. (Lessons in Visual Literacy). New Jersey: Pearson Merrill Prentice Hall, 2003.

Madgil, Richard A. Motor Learning: Concepts and Application. Dubuque: Lowa Wm C. Brown Company, (1988).

Mardanas, Izarwisma, Rifai Abu, dan Maria. Arsitektur Tradisional Sulawesi Selatan. Proyek Inventarisasi Dokumentasi Kebudayaan Daerah Departemen Pendidikan dan Kebudayan Sulawesi Selatan, 1985.

Marzono, Robert J, John Kendall. Taxonomy of Educational Objectives. Book 1: Cognitive Domain. London: Longman LTD, 1979.
Miarso, Yusufhadi. Menyemai Benih Teknologi Pendidikan. Jakarta: Kencana Prenada Media Group, 2009.

Mondy, R. Wayne dan Shane R. Premeuk. Concept, Practice, and Skills. USA: Allyn and Bacon, 1993.

Nitko, Anthony J. Educational Assessment of Student. Third Edition. New Jersey: Englewood Clitts, 2001.

Notoatmodjo, Soekidjo. Ilmu Kesehatan Masyarakat (Prinsip-prinsip Dasar). Jakarta: Rineka Cipta, 2003.

Odum, Eugene P. Fundamentals of Ecology. London: W.B. Saunders Company, 1997.

Parker, Sybil P. Science. Philipinnes: CGraw - Hill. Inc, 1980.

Paul, Vogt W, Tolerance \& Education: Learning to Live With Diversity and Difference. Thousand Oaks, London: SAGE Publication, 1977.

Plomp, Tjeerd and Donald P. Ely. International Encyclopedia of Educational Technology. Canbridge W.K: Cambridge University Press 1996.

Poldum, P. Walton. Environmental Health. New York: Academic Press, 1980.

Predok, Antonie. Architectural Joumeys. New York: Rizzoli International Publication 1995.

Rapoport, A. "Asal Mula Budaya” Pengantar Arsitektur, terjemahan J.C. Snyder \& A.J. Catanese. Jakarta: Erlangga, 1997.

Reizer, Robert A. and John V. Dempsey. Trends and Issues in Instructional Design and Technology (Secon Edition). New Jersey: Pearson Merrill Prentice Hall, 2007.

Roblyer, Margaret D, Aaron H. Doering. Integrating Educational Technologi into Teaching. Fifth Edition. USA: Pearson Education, Inc, 2010.

Romiszowski, AJ. Designing Instructional System, Decision Making in Course Planning and Curriculum Design. New York: Kogan Page London Nicols Publishing, 1981.

Ryan, D.C, Charakteristics of Teacher. A. Research Study Teir Description Comparation, and Appraisal. Washington DC: Ameican Council of Education, 1980. 
Sadiman, Arief S. R. dkk. Media Pendidikan (Pengertian, Pengembangan, dan Pemanfatannya). Jakata: PT. Raja Grafindo Perada, 1986

Sage, George H. Motor Learning and Control: A Neuro-psychological Aproach. Dubuque: lowa Wm C. Brown Publisher, 1984.

Salim, Emil. Lingkungan Hidup dan Pembangunan. Jakarta: Mutiara 1980

Salvato, Joseph A. and Joe E. Beck. Environmental Engineering and Sanitation. New York: Unitet States of America, 1994.

Schaefer, Charles E, Karen Gitlin and Alice Sandgrund, editors. Play Diagnosis and Assessment. New York: John Wiley \& Soons, 1991.

Schiever, Shirly W. A Comprehensive Approach to Teaching. Massachusetts Allyn An Bacon Inc, 1991

Schmidt, Richard A. Motor Control and Learning: A Behavioral Emphasis. Champaign, Illinois: Human Kinetics Publishers, Inc., 1988.

Seels, Barbara B. and Rita C. Richey. Instructional Technology: The Definition and Domains of the Field. Bloomington: Association for Educational Communications and Technology, 1994.

Segall, Mashall $\mathrm{H}$ et al. Human Behavior in Global Perspektive and Introductionto Crooss Cultural Psycology, edition. Boston: Allyn and Baconi, 1999.

Semiawan, Conny R, et.al. Pendekatan Keterampilan Proses. Jakarta: PT. Gramedia, 1988.

Silberman, Mel. Active Training, A Handbook of Techniques Designs, Case Examples, and Tips. New York: Lexington, 2006.

Singer, Dorothy G. and Tracey A. Revenson. A Piaget Primer How a Child Thinks. Revised Edition. USA: A Plume Book, 1996.

Singer, Robert N. Motor Learning and Human Performance an Aplication to Physical Education Skill, $2^{\text {nd }}$ Education. New York: Macmilan Publishing Co. Inc., 1995.

Singer, Robert N. The Psycomotor Domain. Movement Behavier. (London: Henry Kimton Publisher, 1972.

Slamet, Juli Soemirat. Kesehatan Lingkungan. Yogyakarta: Gadjah Mada University Press, 1996.
Smaldino, Sharon E, Deborah L. Lowther, James D. Russell, Instructional Technology and Media for Learning (Ninth Edition). Upper Saddle River, New Jersey: Pearson Education Ltd, 2008.

Soemarwoto, Otto. Ekologi Lingkungan Hidup dan Pembangunan. Jakarta: Djambatan, 1995

Soeriatmaja R.G. Ilmu Lingkungan. Bandung: Institut Teknologi Bandung (ITB), 1984.

Soerjani Moh, Rofiq Ahmad, Rozy Munir. Lingkungan: Sumberdaya Alam dan Kependudukan dalam Pembangunan. Jakarta: UI-Press, 1987.

Sumaatmaja, Nursid. Studi Lingkungan Hidup. Bandung: Alumni, 1989.

Undang-undang Republik Indonesia No. 32 tahun 2009, tentang Perlindungan dan Pengelolaan Lingkungan Hidup. Jakarta, 2009.

Uno, Hamzah B. Model Pembelajaran, Menciptakan Proses Belajar Mengajar yang Kreatif dan Efekif. Jakarta: Bumi Aksara, 2007.

Vogt, W. Paul. Tolerance \& Education: Learning to Live With Diversity and Difference. Thousand Oaks. London: SAGE Publications. 1997.

Werther, William B, and Keith Davis. Human Resourses and Personel Management. New York: McGraw-Hill, 1993

Winarno, F.G. Air Untuk Industri Pangan. Jakarta : P.T. Gramedia, 1986.

Wisner B. and J. Adams. Environmental Health in Emergencies and Disasters. World Health Organization, 2002.

Yaumi. English in Use (A. Practical Way To Reach English Fluency). Jakarta: Restu Agung, 2003

Zahnd Markus. Pendekatan dalam Perancangan Arsitektur. Jakarta: Kanisius, 2009.

Zaifbio. Ranah Penilaian Kognitif, Afektif, dan Psikomotorik. 2009. (http://zaifbio.wordpress.com). 